\title{
The Black/White Binary Paradigm of Race: The "Normal Science" of American Racial Thought
}

\author{
by Juan F. Perea $\dagger$
}

The Black/White Binary Paradigm of race has become the subject of increasing interest and scrutiny among some scholars of color. This Article uses Thomas Kuhn's notions of paradigm and the properties of paradigms to explore several leading works on race. The works the author explores demonstrate the Black/White paradigm of race and some of its properties, among them extensive paradigm elaboration over the years. Paradigms have limitations, however. Among them is a tendency to truncate history for the sake of telling a linear story of progress. The author demonstrates how one constitutional law text truncates history, by omitting entirely Mexican-American struggles for desegregation, and presenting a linear story of the Black struggle for civil rights. Omitting important history from the narrative of civil rights history becomes extraordinarily damaging, since it distorts history and contributes to the marginalization of non-Black peoples of color. While recognizing the centrality of slavery and White racism against Blacks at the core of American history and society, this Article seeks to expand our understanding of racism through the use of legal history. The author contends that mutual and particularized understanding of racism as it affects all people of color has the potential to enhance our abilities to understand each other and to join together to fight the common evil of racism.

American society has no social technique for handling partly colored races. We have a place for the Negro and a place for the white man: the Mexican is not a Negro, and the white man refuses him an equal status. ${ }^{1}$

Copyright $\odot 1997$ California Law Review, Inc.

$i$ Professor of Law, University of Florida College of Law. My thanks to Dean Richard Matasar and to Professors Charles Collier, Richard Delgado, Joe Feagin, Jeff Harrison, Cynthia Lee, Lyrissa Lidsky, Sharon Rush, Chris Slobogin, Hemán Vera and Walter Weyrauch for reading and 
This Article is about how we are taught to think about race. In particular, I intend to analyze the role of books and texts on race in structuring our racial discourse. I believe that much writing on racism is structured by a paradigm that is widely held but rarely recognized for what it is and what it does. This paradigm shapes our understanding of what race and racism mean and the nature of our discussions about race. It is crucial, therefore, to identify and describe this paradigm and to demonstrate how it binds and organizes racial discourse, limiting both the scope and the range of legitimate viewpoints in that discourse.

In this Article, I identify and criticize one of the most salient features of past and current discourse about race in the United States, the Black/White binary paradigm of race. A small but growing number of writers have recognized the paradigm and its limiting effect on racial discourse. $^{2}$ I believe that its dominant and pervasive character has not been well established nor discussed in legal literature.

I intend to demonstrate the existence of a Black/White paradigm and to show its breadth and seemingly pervasive ordering of racial

commenting on previous drafts of this article. This article was made possible by a Univcrsity of Florida Law Center Foundation Summer Research grant. Thanks also to Mr. John Marshall, my wonderful research assistant, a distinguished graduate of the University of Florida College of Law. Thanks also to the editors and staff of the California Law Review and La Raza Law Journal for helpful comments and for the courage to publish works that challenge the dominant paradigm.

1. Max Handman, quoted in David Montejano, ANglos and Mexicans in the Making OF TEXAs, 1836-1986, 158 (1987).

2. See, e.g., Robert S. Chang, Toward an Asian American Legal Scholarship: Critical Race Theory, Post Structuralism, and Narrative Space, 81 CALIF. L. REv. 1243, 1267 (1993) ("To focus on the black-white racial paradigm is to misundcrstand the complicated racial situation in the United States."); Adrienne D. Davis, Identity Notes Part One: Playing in the Light, 45 AM. U. L. Rev. 695, 696 (1996) ("An historical assessment of the relationship of other groups of color to a black/white paradigm reveals the paradigm as not only undescriptive and inaccurate, but debilitating for legal analysis, as well as civil rights oriented organizing."); Richard Delgado, Rodrigo's Fifteenth Chronicle: Racial Mixture, Latino-Critical Scholarship, and the Black-White Binary, 75 TEx. L. Rev. 1181 (1997); Angela Harris, Foreword: The Jurisprudence of Reconstruction, 82 CALIF. L. REv. 741, 775 \& n.169 (1994) ("Race-crits' understanding of 'race' and 'racism' might also benefit from looking beyond the struggle between black and white. African American thcorists have, until now, dominated C[ritical] R[ace] T[heory], and African American expericnces have been taken as a paradigm for the experiences of all people of color."); Deborah Ramirez, Multicultural Empowerment: It's Not Just Black and White Anymore, 47 STAN. L. REv. 957, 957-59 (1995); William R. Tamayo, When the "Coloreds" Are Neither Black nor Citizens: The Uniled States Civil Rights Movement and Global Migration, 2 AsıAN LJ. 1, 7-9 (1995); Frank Wu, Neilher Black nor White: Asian Americans and Affirmative Action 15 B.C. THIRD WORLD L.J. 225, 248 (1995) ("The time has come to consider groups that are neither black nor white in the jurisprudence of race.... Bipolarity is an organizational scheme both imposed by and reflected in the law. Bipolarity has been associated with essentialism in the conception of race. Race is conceptualized as breaking down into two all-encompassing and mutually exclusive categories, black and white."); see also Elizabeth Martinez, Beyond Black/White: The Racisms of our Time, 20 Soc. Just. 22 (1994). 
discourse and legitimacy. Further, I intend to show how the Black/White binary paradigm operates to exclude Latinos/as ${ }^{3}$ from full membership and participation in racial discourse, and how that exclusion serves to perpetuate not only the paradigm itself but also negative stereotypes of Latinos/as. Full membership in society for Latinos/as will require a paradigm shift away from the binary paradigm and towards a new and evolving understanding of race and race relations.

This Article illustrates the kind of contribution to critical theory that the emergent Latino Critical Race Studies (LatCrit) movement may make. This movement is a continuing scholarly effort, undertaken by Latino/a scholars and other sympathetic scholars, to examine critically existing structures of racial thought and to identify how these structures perpetuate the subordinated position of Latinos/as in particular. LatCrit studies are, then, an extension and development of critical race theory (and critical theory generally) that focus on the previously neglected areas of Latino/a identity and history and the role of racism as it affects Latinos/as.

I identify strongly, and self-consciously, as a Latino writer and thinker. It is precisely my position as a Latino outsider, neither Black nor White, that makes possible the observation and critique presented in this Article. My critique of the Black/White binary paradigm of race shows this commonly held binary understanding of race to be one of the major impediments to learning about and understanding Latinos/as and their history. As I shall show, the paradigm also creates significant distortions in the way people learn to view Latinos/as.

I begin with a review of the principal scientific theory that describes the nature of paradigms and the power they exert over the formation of knowledge. I then analyze important, nationally recognized books on race to reveal the binary paradigm of race and the way it structures race thinking. After reviewing these popular and scholarly books on race, I analyze a leading casebook on constitutional law. Like other books, textbooks on constitutional law are shaped by the paradigm and reproduce it. Then, by describing some of the legal struggles Latinos/as have waged, I will demonstrate that paradigmatic presentations of race and struggles for equality have caused significant omissions with undesirable repercussions. Thus, I demonstrate the important role that legal history

3. I make conscious use of the construction Latino/a to avoid exacerbating the problems of invisibility faced by Latinas. "Latino" is a male-gendered term, and in my references to Latinos/as and our history, I intend to include both Latinos and Latinas. 
can play in both correcting and amplifying the Black/White binary paradigm of race.

\section{I}

\section{THEORETICAL Foundations}

\section{A. The Power of Paradigms}

Thomas Kuhn, in The Structure of Scientific Revolutions, ${ }^{4}$ describes the properties of paradigms and their power in structuring scientific research and knowledge. While Kuhn develops his understanding of paradigms in evaluating the development of scientific knowledge, many of his insights are useful in understanding paradigms and their effects more generally. A paradigm is a shared set of understandings or premises which permits the definition, elaboration, and solution of a set of problems defined within the paradigm. ${ }^{5}$ A paradigm is an accepted model or pattern that, "like an accepted judicial decision in the common law ... is an object for further articulation and specification under

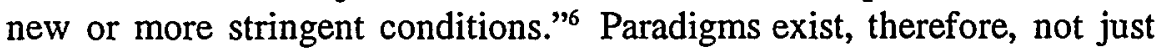
in the sciences but also in law and other disciplines. ${ }^{7}$

Thus, a paradigm is the set of shared understandings that permits us to distinguish those facts that matter in the solution of a problem from those facts that do not. As Kuhn writes,

[i]n the absence of a paradigm or some candidate for paradigm, all of the facts that could possibly pertain to the development of a given science are likely to seem equally relevant. As a result, early fact-gathering is a far more nearly random activity than the one that subsequent scientific development makes familiar. ${ }^{8}$

Paradigms thus define relevancy. In so doing, paradigms control factgathering and investigation. Data-gathering efforts and research are focused on understanding the facts and circumstances that the relevant paradigm teaches us are important.9

Paradigms are crucial in the development of science and knowledge because, by setting boundaries within which problems can be

4. Thomas S. Kuhn, The Structure of Scientific Revolutions (2d ed. 1970).

5. See id. at 37.

6. Id. at 23.

7. For an apt application of Kuhnian principles to the unsettled premises of interdisciplinary legal scholarship, see Charles W. Collier, Interdisciplinary Legal Scholarship in Search of a Paradigm, 42 DUKE L.J. 840 (1993).

8. KuHN, supra note 4, at 15.

9. See id. at 25 (describing the normal foci for factual investigation: "First is that class of facts that the paradigm has shown to be particularly revealing of the nature of things."). 
understood, they permit detailed inquiry into these problems. In Kuhn's words, a "paradigm forces scientists to investigate some part of nature in a detail and depth that would otherwise be unimaginable."10 Indeed, it is this depth of research that eventually yields anomalies and discontinuities and, ultimately, the necessity to develop new paradigms. However, as a paradigm becomes the widely accepted way of thinking and of producing knowledge on a subject, it tends to exclude or ignore alternative facts or theories that do not fit the expectations produced by the paradigm."

Kuhn uses the concept of "normal science" to describe the elaboration of the paradigm and the solution of problems that the paradigm allows us to perceive. ${ }^{12}$ Scientists and researchers spend almost all of their time engaged in normal science, conducting their research under the rules prescribed by the paradigm and attempting to solve problems cognizable and derivable from the paradigm. However, normal science "often suppresses fundamental novelties because they are necessarily subversive of its basic commitments." ${ }^{13}$ As Kuhn describes, normal science "seems an attempt to force nature into the performed and relatively inflexible box that the paradigm supplies. No part of the aim of normal science is to call forth new sorts of phenomena; indeed those that will not fit the box are often not seen at all."14 As normal research progresses in depth and detail within a paradigm, researchers make unexpected discoveries, yielding anomalies that the current paradigm does not adequately explain. In time, and in the face of problems not adequately explained by the paradigm, scientists are forced to abandon the old paradigm and replace it with some new understanding that better explains the observed anomalies. ${ }^{15}$

Literature and textbooks play an important role in producing and reproducing paradigms. Kuhn identifies textbooks and popular literature, which convey scientific knowledge in a language more accessible to the general public, as authoritative sources of established paradigms. ${ }^{16}$ Textbooks and derivative literature intend to communicate the particular

10. Id. at 24 .

11. See id.

12. See id. at 113 ("Something like a paradigm is prerequisite to perception itself.").

13. Id. at 5.

14. Id. at 24 .

15. See id. at 7 (suggesting that assimilation of a new theory "requires the reconstruction of prior theory and the re-evaluation of prior fact, an intrinsically revolutionary process that is seldom completed by a single man and never overnight").

16. See id. at 136-37. 
paradigm or set of paradigms that constitute the current tradition of a science. ${ }^{17}$

Interestingly, Kuhn observes that textbooks must distort history significantly in order to convey the current state of a discipline in a linear, coherent way. ${ }^{18}$ Textbooks truncate "the scientist's sense of his discipline's history and then proceed to supply a substitute for what they have eliminated."19 In order to do this, textbooks present only a small part of history-the portion of history that authors can easily present as contributing to the development and solution of today's paradigm problems. ${ }^{20}$ "The result," in Kuhn's words, "is a persistent tendency to make the history of science look linear or cumulative."21 In other words, textbooks distort history to make it appear that the current paradigm, or current knowledge, is the result of a linear, related series of discoveries or events in which each subsequent event is causally linked to the prior events. ${ }^{22}$ This distortion requires leaving out all of the historical complexity and the revolutionary questions and ideas on which new scientific discoveries and new paradigms depend. Kuhn terms this distortion of history "depreciation of historical fact."

Although Kuhn suggests that science is more vulnerable to textbook distortions of history than other disciplines because of the assumed objectivity of scientific inquiry, ${ }^{24} \mathrm{I}$ believe his insights regarding paradigms, "normal science," and textbooks are extremely useful in explaining the persistent focus of race scholarship on Blacks and Whites, and the resulting omission of Latinos/as, Asian Americans, Native Americans, and other racialized groups from such scholarship. If science as a discipline is more vulnerable to textbook distortions of history, I believe this is only a matter of degree, as law, through its reliance on precedent, is also highly dependent on paradigms. Kuhn recognized as much when he used judicial precedent, and subsequent decisions based on precedent, as an example of paradigm elaboration. ${ }^{25}$ Although Kuhn felt that the extent to which the social sciences had developed paradigms was an open question, ${ }^{26} \mathrm{I}$ suggest in this Article that
17. See id.
18. See id. at 136-39.
19. Id. at 137.
20. See id. at 138 .
21. Id. at 139.
22. See id. at 138 .
23. Id.
24. See, e.g., id.
25. See id. at 23.
26. See id. at 15. 
race scholarship both inside and outside of law is dominated by a binary paradigm of race. Like science textbooks, constitutional law textbooks also distort history for the sake of a paradigmatic, linear presentation of the evolution of equality doctrines.

\section{B. Describing the Binary Paradigm of Race}

Paradigms of race shape our understanding of race and our definition of racial problems. The most pervasive and powerful paradigm of race in the United States is the Black/White binary paradigm. I define this paradigm as the conception that race in America consists, either exclusively or primarily, of only two constituent racial groups, the Black and the White. Many scholars of race reproduce this paradigm when they write and act as though only the Black and the White races matter for purposes of discussing race and social policy with regard to race. The mere recognition that "other people of color" exist, without careful attention to their voices, their histories, and their real presence, is merely a reassertion of the Black/White paradigm. If one conceives of race and racism as primarily of concern only to Blacks and Whites, and understands "other people of color" only through some unclear analogy to the "real" races, this just restates the binary paradigm with a slight concession to demographics.

My assertion is that our shared understanding of race and racism is essentially limited to this Black/White binary paradigm. ${ }^{27}$ This paradigm defines, but also limits, the set of problems that may be recognized in racial discourse. Kuhn's notion of "normal science," which further articulates the paradigm and seeks to solve the problems perceivable because of the paradigm, also applies to "normal research" on race.

Given the Black/White paradigm, we would expect to find that much research on race is concerned with understanding the dynamics of the Black and White races and attempting to solve the problems between

27. The idea that knowledge is socially constructed, and therefore both contingent upon the values of a society and highly formative of those values in subsequent generations, is by now well established as a premise of critical theory. See generally Peter L. Berger \& Thomas LuckManN, The Social CONSTRUCTION OF REALITY (1966). Writers on the subject of race have established forcefully that any concept of "race" itself is a highly contingent and mutable social construction. See Ian Haney Lopez, The Social Construction of Race: Some Observations on Illusion, Fabrication and Choice, 29 Harv. C.R.-C.L. L. Rev. 1, 10 (1994); see also Michael OMI \& Howard WiNANt, RACIAL Formation IN THE UNITED States 55-56 (2d ed. 1994). The understanding of race as a social construction does not mean that race is not real. It is both real and profoundly determinative of how we experience our lives and identities. 
Blacks and Whites. Within the paradigm, the relevant material facts are facts about Blacks and Whites.

In addition, the paradigm dictates that all other racial identities and groups in the United States are best understood through the Black/White binary paradigm. Only a few writers even recognize that they use a Black/White paradigm as the frame of reference through which to understand racial relations. ${ }^{28}$ Most writers simply assume the importance and correctness of the paradigm, and leave the reader grasping for whatever significance descriptions of the Black/White relationship have for other people of color. As I shall discuss, because the Black/White binary paradigm is so widely accepted, other racialized groups like Latinos/as, Asian Americans, and Native Americans are often marginalized or ignored altogether. As Kuhn writes, "those that will not fit the box are often not seen at all."29

Scholarly literature, textbooks, and popular literature on race are crucial in reifying and transmitting the binary paradigm..$^{30}$ In the realm of scholarly literature, I begin by analyzing Andrew Hacker's famous Two Nations: Black and White, Separate, Hostile, Unequal. I then study Cornel West's Race Matters. These books, by leading scholars on race, both illustrate the existence and use of the Black/White binary paradigm. They show how the paradigm results in an exclusive focus on Blacks and Whites, both from the point of view of a White writer and a Black writer. The paradigm also leads to the marginalization of other non-White people, again borne out by both writers. Both Hacker and West exhibit astonishing indifference with regard to the history of racism against non-Black people of color.

I continue by analyzing three scholarly books on White racism. These books, all titled White Racism, are particularly instructive, because they suggest both the continuity of the paradigm across a span of twenty-five years of scholarly inquiry on White racism and also the kind of paradigm elaboration and development described by Kuhn. The first book, edited by Barry N. Schwartz and Robert Disch, appeared in 1970. The second, by psychoanalyst Joel Kovel, was published in a new

28. See, e.g., Joe Feagin \& Hernan Vera, White Racism xii (1995); Georfrey R. Stone et al., Constitutional Law 471-72 (2d ed. 1991).

29. KuHN, supra note 4, at 24; see also Juan F. Perea, Los Olvidados: On the Making of Invisible People, 70 N.Y.U. L. Rev. 965 (1995); ANNE SUtherLANd, Gypsies: The Hidden AMERICANS (1986).

30. Because the literature on race is so vast, I must neccssarily rely on a limited sample of major works on race. Even this limited sample reveals the Black/White binary paradigm and its operation. 
edition in 1984. The third, by sociologists Joe R. Feagin and Hernan Vera, was published in 1995. Taken together, these books illustrate both the possibilities and the limits of the Black/White paradigm. The paradigm makes possible more detailed and nuanced treatment and understanding of White racism against Blacks; simultaneously, the paradigm steadily reinforces the exclusion of other non-Whites.

Finally, I will turn to the textbook, a premier source and promulgator of the paradigm. I analyze a leading casebook on constitutional law whose section on race and equality is shaped by and reproduces the Black/White binary paradigm. I conclude by demonstrating how the introduction of relevant Mexican-American legal history into the treatment of constitutionally significant racial issues has the power to alter the paradigm and to produce a very different understanding of the struggle for equality under the Constitution.

\section{II}

\section{Paradigm Production: The Scholarly Literature on Race}

I believe that study and criticism of White racism against Blacks is crucial and contributes in important ways to our understanding of how racism works. ${ }^{31}$ The problem that I perceive in much literature on race is that it comprehends only the study of White racism against Blacks as the legitimate scope of racism. I will show in this section how this reliance on the binary paradigm leads to the exclusion and marginalization of other racialized people who also suffer from racism. What is necessary, in the end, is an appreciation for the particular histories of all racialized peoples, and a broader concept of racism that encompasses the different ways that racism afflicts different people.

\section{A. Andrew Hacker and the Two Nations}

Andrew Hacker's famous book, Two Nations: Black and White, Separate, Hostile, Unequal, provides an excellent exainple of reliance on the Black/White binary paradigm. ${ }^{32}$ Its title, proclaiming two nations, Black and White, boldly professes the binary paradigm. Although Hacker recognizes explicitly that a full perspective on race in America requires inclusion of Latinos/as and Asians, ${ }^{33}$ this recognition is, in the

31. See generally Joe R. Feagin \& MeLvin P. SiKes, Living with RaClsM: THE BLACK MIDDLE-CLASS EXPERIENCE (1994) (describing in detail, through extensive interviews, the pervasive everyday racism experienced by middle-class Blacks).

32. Andrew Hacker, Two Nations: Black and White, Separate, Hostlle, Unequal (1992).

33. See id. at xii. 
context of the entire book, insignificant and nnderdeveloped. His almost exclusive focus on Blacks and Whites is clearly intentional: "Two Nations will adhere to its title by giving central attention to black and white Americans." ${ }^{34}$

Hacker's justification for this focns is that "[i]n many respects, other groups find themselves sitting as spectators, while the two prominent players try to work out how or whether they can coexist with one another."${ }^{35}$ This justification perpetuates the marginalization of the already marginalized. Hacker and so many other writers on race decline to understand that, by focusing only on Blacks and Whites, they both produce and replicate the belief that there are only "two prominent players," Black and White, in debates about race. These writers thus render other non-White groups invisible and implicitly characterize them as passive, voluntary spectators. Such characterization is contrary to the history of these groups. ${ }^{36}$

Hacker describes in detail only conditions experienced by White or Black Americans. He first characterizes the White nature of the nation and its culture:

America is inherently a "white" country: in character, in structure, in cnlture. Needless to say, black Americans create hives of their own. Yet, as a people, they face boundaries and constrictions set by the white majority. America's version of apartheid, while lacking overt legal sanction, comes closest to the system even now being reformed in the land of its invention. ${ }^{37}$

Of course, Latinos/as, Asian Americans, Native Americans, Gypsies, and all non-White Americans face "boundaries and constrictions set by the white majority," but the vision Hacker advances counts only Blacks as significantly disadvantaged by White racism.

Similarly, Hacker describes Blackness as uniquely functional for Whites:

As James Baldwin has pointed out, white people need the presence of black people as a reminder of what providence has spared them from becoming. ... In the eyes of white Americans, being black encapsulates your identity. No other racial or national origin is seen as having so pervasive a personality or character. $^{38}$

34. Id.

35. Id.

36. See infra Part III.

37. HACKER, supra note 32, at 4 .

38. Id. at 30,32 . 
According to Hacker, then, Blackness serves a crucial function in enabling Whites to define themselves as privileged and superior, and racial attributes of other minorities do not serve this function.

Hacker's chapter titles largely tell the story of the binary paradigm. Chapter two, on "Race and Racism," discusses only White and Black perceptions of each other. Chapter three, "Being Black in America," is followed by a chapter on "White Responses."

Hacker's omission of non-Black minority groups in his discussion of specific topics similarly suggests that these groups' experiences do not exist. Chapter nine, on segregated schooling, describes only the experience of Black segregation. This chapter makes no reference to the extensive history of segregation in education suffered by Latinos/as. ${ }^{39}$ Chapter ten asks, "What's Best for Black Children?" with no commensurate concern for other children. Similarly, Chapter eleven, on crime, discusses only perceptions of Black criminality and their interpretation. In discussing police brutality, Hacker describes only White police brutality against Blacks. There is not a single word about the similar police brntality suffered by Latino/a people at the hands of White police officers. $^{40}$ Nor are there any words in these chapters describing the experiences of Native Americans or Asian Americans.

The greatest danger in Hacker's vision is its suggestion that nonWhite groups other than Blacks are not really subject to racism. Hacker seems to adopt the deservedly criticized ethnicity theory, ${ }^{41}$ which posits that non-White immigrant ethnics are essentially Whites-in-waiting who will be permitted to assimilate and become White. ${ }^{42}$ This is illustrated best in Chapter eight, "On Education: Ethnicity and Achievement," which offers the book's only significant discussion of non-White

39. For a discussion of the history of segregation in education suffered by Latinos/as, see George A. Martinez, Legal Indeterminacy, Judicial Discretion and the Mexican-American Litigation Experience: 1930-1980, 27 U.C. DAvis L. REv. 555, 574-602 (1994); see generally Jorge C. Rangel \& Carlos M. Alcala, Project Report: De Jure Segregation of Chicanos in Texas Schools, 7 HaRv. C.R.-C.L. L. REv. 307 (1972). For an excellent study of the segregation of Mexican American children, see Gilbert G. Gonzalez, Chicano Education in the Era of Segregation (1990); see also U.S. COMm. ON Civil Rights, Mexican AMERICAN Education Study, Rep 1: Ethnic Isolation of Mexican Americans in the Public Schools of the Southwest (1971). For further discussion of this history, see infra Part V.

40. See, e.g., U.S. Comm. ON Civil Rights, MExican AMERICANS and the AdMinistration OF JUSTICE IN THE SOUTHWEST (1970) (documenting the severe discrimination against Mexican Americans in all phases of the justice system); see generally NANCY L. GeILHUfE, Chicanos and the Police (1979); Coramae Richey ManN, Unequal Justice: A Question of CoLor (1993).

41. See Haney López, supra note 27, at 20-24.

42. See HACKER, supra note 32 , at 1-16. 
groups other than Blacks. Hacker describes Asians in "model minority" terms, because of high standardized test scores as a group. ${ }^{43} \mathrm{He}$ portrays Latinos/as as below standard, because of low test scores and graduation rates, and as aspiring immigrants. ${ }^{44}$ Describing Asian Americans, Latinos/as and other immigrant groups, Hacker writes:

Members of all these "intermediate groups" have been allowed to put a visible distance between themselves and black Americans. Put most simply, none of the presumptions of inferiority associated with Africa and slavery are imposed on these other ethnicities. ${ }^{45}$

While a full rebuttal of this proposition is beyond the scope of this Article, its inaccuracy can be quickly demonstrated. Consider, for instance, the observations of historian David Weber, who described early Anglo perceptions of Mexican people: "American visitors to the Mexican frontier were nearly unanimous in commenting on the dark skin of Mexican mestizos who, it was generally agreed, had inherited the worst qualities of Spaniards and Indians to produce a 'race' still more despicable than that of either parent." ${ }^{346}$ Rufus B. Sage expressed the common view of Mexicans in 1846:

There are no people on the continent of America, whether civilized or uncivilized, with one or two exceptions, more miserable in condition or despicable in morals than the mongrel race inhabiting New Mexico.... To manage them successfully, they must needs be held in continual restraint, and kept in their place by force, if necessary,-else they will become haughty and insolent. As servants, they are excellent, when properly trained, but are worse than useless if left to themselves. ${ }^{47}$

More briefly, the common perception of Mexican Americans was that "They are an inferior race, that is all."

43. See id. at $140-44$.

44. Compare id. at 137-39 ("Across from [Asian students] will be blacks and Hispanics with classroom skills at a rather lower level.") with id. at 146 ("Aspiring middle-class Hispanics have outlooks similar to those found among Asians.").

45. Id. at 16 .

46. David J. Weber, Editor's Introduction to Chaper II, in ForeIGNers iN THeIR NATIVE LaND: Historical Roots of THE Mexican Americans 59 (David J. Weber ed., 1973).

47. Id. at 72, 74 (quoting 2 RufuS B. SAGE: HIS LetreRS AND PAPERS, 1836-1847 (LeRoy R. and Ann W. Hafen eds., 1956)).

48. Texas school officials offered this justification for segregating Mexican Americans in 1929. See Rangel \& Alcala, supra note 39, at 307 (quoting PAUL Schuster TAYLOR, AN AMERICAN MEXICAN Frontier 219 (1934)). 
Incredibly, and without any supporting evidence, Hacker writes that "[m]ost Central and South Americans can claim a strong European heritage, which eases their absorption into the 'white' middle class."49 Hacker continues, "[w]hile immigrants from Colombia and Cyprus may have to work their way up the social ladder, they are still allowed as valid a claim to being 'white' as persons of Puritan or Pilgrim stock." 50 Hacker's comments are simply incredible for their blithe lack of awareness of how racism burdens the lives of Latino/a, Asian American and other racialized immigrant groups. While some Latinos/as may look White and may act Anglo (the phenomenon of passing for White is not limited to Blacks), Hacker's statement is certainly false for millions of Latinos/as. Current anti-immigrant initiatives targeted at Latinos/as and Asians, such as California's Proposition $187^{51}$ and similar federal legislation targeting legal and illegal immigrants, ${ }^{52}$ California's Proposition 209,53 and unprecedented proposals to deny birthright citizenship to the United States-born children of undocumented persons, debunk any notion that the White majority tolerates easily the presence of Latino/a or Asian people. ${ }^{54}$

Ultimately, Hacker seems determined to adhere to the binary paradigm of race and to ignore the complexity introduced by other nonWhite groups, because it is convenient-which, it will be recalled, is a principal danger of paradigms. In the statistical section of the book, Hacker explains some of the problems with statistics he reproduces:

Some government publications place persons of Hispanic origin within the black and white racial groupings. Others put them in a separate category, to differentiate them from blacks and whites.

49. HACKER, supra note 32, at 10.

50. Id. at 12.

51. This initiative, passed in 1994 but largely enjoined by a federal district court, League of United Latin American Citizens v. Wilson, 988 F. Supp. 755 (C.D.Cal. 1995), would limit or deny undocumented immigrants access to social welfare benefits.

52. See Personal Responsibility and Work Opportunity Reconciliation Act of 1996, 42 U.S.C.A. $\S 601$ et seq. (West Supp. 1997); Illegal Immigrant and Immigration Reform Act of 1996, Pub.L. 104208, 110 Stat. 3009-546 (codified as amended in scattered sections of 8 U.S.C.).

53. This was the so-called "Civil Rights Initiative," passed in 1996, that would prohibit race and gender considerations in public hiring, contracting, and educational programs in California. Proposition 209 went into effect following the Supreme Court's denial of a stay pending decision on grant of certiorari following the Ninth Circuit's decision to uphold the initiative. Coalition for Economic Equity v. Wilson, I10 F.2d 1431 (9th Cir. 1997), cert. denied, 66 U.S.L.W. 3316, 66 U.S.L.W. 3324 (U.S. Nov. 3, 1997), (No. (97-369).

54. See generally Immigrants OUt! The New Nativism and the ANTI-IMmigRant Impulse IN THE UNITEd StaTes (Juan F. Perea ed., I997) [hereinafter IMmigrants OUT!] (describing in detail the series of anti-immigrant proposals targeted at Latinos/as and Asians and placing these proposals in the context of American nativism). 
Wherever the sources permit, Two Nations has separated out Hispanics, to keep the book's emphasis on race as coherent as possible. Where this has not been possible, readers should bear in mind that the figures for whites may be inflated by the inclusion of considerable numbers of Hispanics. ${ }^{55}$

Although government publications have confused the ability to count Latinos/as, ${ }^{56}$ what is startling here is Hacker's vision that coherence in discussion of race requires emphasis on only Black and White. In other words, "real" race is only Black or White. Other groups only render this framework "incoherent." This is why the Black/White paradigm of race must be expanded: it causes writers like Hacker to ignore other non-White Americans, which in turn encourages others to ignore us as well.

\section{B. Cornel West and the Black-White Binary Paradigm}

Cornel West is one of the most well known and well regarded philosophers and commentators on race in the nation. While West writes with much more insight than Hacker, his recent book Race Matters also reproduces the Black/White binary paradigm of race. ${ }^{57}$ Several of the essays seem addressed chiefly to the Black community, and some to the Black and White communities. His critiques of Black leadership, intellectuals, and conservatism are powerful, unflinching, and persuasive.

To a large extent, however, West adopts the Black/White binary paradigm by addressing only the relationship between Blacks and Whites (and, in one essay, Blacks and Jews). West writes as though "race" means only the Black race. His remarks confine the discussion of race and anti-racism to the need to struggle against Black oppression, rather than a broader anti-subordination agenda that would include all people of color and anti-racist Whites in confronting patriarchy and racism in all their manifestations.

West correctly recognizes, in one sentence, the "multiracial, transclass, and largely male display of justified social rage" that occurred during the Los Angeles riots of $1992 .{ }^{58}$ West notes that only 36 percent of those arrested were Black (51 percent of those arrested were Latino,

55. HACKER, supra note 32, at 223 (emphasis added).

56. See Ramirez, supra note 2, at 959 n.7 ("[P]rior to the 1970 census, the concept of Hispanics as a group barely existed .... [N]one of the identifiers used prior to 1970 could satisfy the need for a definition that could be applied nationwide. ..." (quoting Cary Davis et al., U.S. Hispanics: Changing the Face of America, 38 Population Bull. 3, 5 (1983))).

57. Cornel. West, Race Matters (1993).

58. Id. at 1 . 
making the riots and looting prominently Latino).$^{59}$ But rather than discuss the multiracial rage and despair that fueled the riots, West discusses the inadequacy of our racial discourse in binary, Black/White terms. West describes the kind of discussions that we need to have about race in terms suggesting that only Blacks and Whites need to participate in the discussion:

To engage in a serious discussion of race in America, we must begin not with the problems of black people but with the flaws of American society-flaws rooted in historic inequalities and long-standing cultural stereotypes. How we set up the terms for discussing racial issues shapes our perception and response to these issues. As long as black people are viewed as a "them," the burden falls on blacks to do all the "cultural" and "moral" work necessary for healthy race relations.

... [W]e confine discussions about race in America to the 'problems' black people pose for whites rather than consider what this way of viewing black people reveals about us as a nation.... Both [liberals and conservatives] fail to see that the presence and predicaments of black people are neither additions to nor defections from American life, but rather constitutive elements of that life. ${ }^{60}$

West's statements are accurate, and I would fault West only for not recognizing (if indeed he does not) that exactly the same statements apply to Latinos/as, Asian Americans and Native Americans as well as Blacks. If the "terms for discussing racial issues" include only Blacks and Whites, this fact will indeed shape everyone's perception of who belongs in the discussion, and Latinos/as, Asian Americans and Native Americans will promptly disappear. Any serious discussion of race requires incorporating the multiple points of view of all racialized peoples. Like Blacks, Latinos/as, Asian Americans, and Native Americans are all constitutive of American life and identity to a degree that has not been fully recognized and is, in fact, actively resisted.

West's near-exclusive focus on Blacks and Whites, and thus his reproduction of the Black/White binary paradigm, is apparent throughout the book. Chapter two, entitled "The Pitfalls of Racial Reasouing," presents a powerful critique of racial reasoning within the Black community that immobilized Black leaders and prevented them from

59. For a discussion of the media's misportrayal of the riots as a Black/White and Black/Korean event, see Perea, supra note 29, at 967-70.

60 . WEST, supra note 57 , at 2-3. 
criticizing Clarence Thomas when he was appointed to the Supreme Court. ${ }^{61}$ West's binary conception of the nation emerges when he describes the "deep cultural conservatism in white and black America. In white America, cultural conservatism takes the form of a chronic racism, sexism, and homophobia .... In black America, cultural conservatism takes the form of a [sic] inchoate xenophobia (e.g., against whites, Jews, and Asians), systemic sexism, and homophobia."62 Like Hacker's conception of "two nations," West sees binary Americas, one White, one Black. In addition, West's reference to Black xenophobia, directed at Whites, Jews, and Asians, sets the stage for his later description of Black distrust of Latinos/as as well.

West also describes the binary paradigm from a Black point of view, referring to the "black bourgeois preoccupation with white peer approval and black nationalist obsession with white racism." ${ }^{63}$ Blacks, in their way, are as preoccupied with Whites as Whites are with Blacks.

In his chapter on "Malcolm X and Black Rage," West describes Malcolm X's fear of cultural hybridity, the blurring of racial boundaries that occurs because of racial mixture. ${ }^{64}$ Malcolm $X$ saw such hybridity, exemplified by mulattoes, as "symbols of weakness and confusion." 65 West's commentary on Malcolm X's views gives us another statement of the binary paradigm: "The very idea of not 'fitting in' the U.S. discourse of positively valued whiteness and negatively debased blackness meant one was subject to exclusion and marginalization by whites and blacks." Although the context of this quotation is about Black/White mulattoes, West's observation is crucial to an understanding of why Latinos/as, neither claiming to be, nor being, White or Black, are perpetually excluded and marginalized. The reified binary structure of discourse on race leaves no room for people of color who do not fit the rigid Black and White boxes supplied by the paradigm. Furthermore, most Latinos/as are mixed race mestizos or mulattoes, who therefore embody the kind of racial mixture that Malcolm X, and, I

61. See id. at 21-32.

62. Id. at 27 .

63. Id. at 66 .

64. See id. at 103.

65. Id. It is interesting to note the similarity between Malcolm X's sense that mixcd-race people introduced "confusion" into the otherwise clear structures of Black and White, and Andrew Hacker's sense that Hispanics introduce "incoherence" into the otherwise "clear" vision of Black and White races. These observations suggest one reason for the continued adherence to a Black/White paradigm despite its inadequacy: the paradigm does simplify, and makes racial problems more readily understood, than if we began to grapple with them in their full complexity.

66. Id. 
would argue, society generally tends to reject. West's observation about mixed-race people who do not fit within traditional U.S. discourse about race applies in full measure to Latinos/as.

When West writes about the struggle for Black civil rights in shaping the future of equality in America, he recognizes the need for Blacks to repudiate anti-Semitism and other racisms in order to sustain the moral position garnered through the struggle for civil rights. ${ }^{67}$ I agree with West that a strategy of coalition is preferable to racial reasoning that results in a closed-ranks mentality. ${ }^{68}$ However, West's remarks do not acknowledge the extensive struggles for civil rights in which other groups have engaged. Indeed, West expresses a degree of distrust regarding Latinos/as and Asian Americans that works against the coalitions that West knows are necessary to struggle successfully against racism:

[A] prophetic framework encourages a coalition strategy that solicits genuine solidarity with those deeply committed to antiracist struggle.... [B]lack suspicions of whites, Latinos, Jews, and Asians runs deep for historical reasons. Yet there are slight though significant antiracist traditions among whites, Asians, and especially Latinos, Jews and indigenous people that must not be cast aside. Such coalitions are important precisely because they not only enhance the plight of black people but also because they enrich the quality of life in America. ${ }^{69}$

This paragraph warrants further probing. Given America's history of racism, Black suspicions of every group may seem well-founded. For example, with respect to Latinos/as, during the nineteenth century as during the present, identification with Anglos by upper-class Mexicans meant becoming more racist and disparaging toward lower-class and darker-skinned Mexicans and Blacks. ${ }^{70}$ However, West's characterization of Latino/a, Asian, and Native American resistance to White racism as "slight though significant"71 seems belittling, ill-informed, and marginalizing of Latino/a, Asian, and indigenous people." This comment

67. See id. at 75 .

68. See id. at 28.

69. Id. at 28-29.

70. For example, in the late nineteenth century, rich Mexicans supported the Ku Klux Klan and White supremacy even when lower-class Mexicans were the victims. See Rodolfo Acuña, OCCUPIED AMERICA: A History OF CHICANOS 34 (3d ed. 1988).

71. WEST, supra note 57 , at 28.

72. For treatment of Latino/a and Asian resistance, see generally ACUÑA, supra note 70; Sucheng Chan, This Bittersweet Soll: The Chinese in California Agriculture, 1860-1910 
can be understood as the kind of "inchoate xenophobia" West himself finds in the Black community. ${ }^{73}$

Another possible reason for this distrust of Latinos/as may stem from a widespread sense that immigrant Latinos/as are displacing Blacks. ${ }^{74}$ Toni Morrison writes specifically about this Black distrust of immigrants. In her essay "On the Backs of Blacks," Morrison describes the hatred of Blacks as the defining, final, necessary step in the Americanization of immigrants. ${ }^{75}$ "It is the act of racial contempt [banishing a competing black shoe-shiner] that transforms this charming Greek into an entitled white. ${ }^{" 76}$ Morrison sees Blacks as persistently victimized by Americanizing processes, always forced to "the lowest level of the racial hierarchy." The struggles of immigrants, according to Morrison,

are persistently framed as struggles between recent arrivals and blacks. In race talk the move into mainstream America always means buying into the notion of American blacks as the real aliens. Whatever the ethnicity or nationality of the immigrant, his nemesis is understood to be African American. ${ }^{78}$

Morrison is right that American "Whiteness" is often achieved through distancing from Blacks. ${ }^{79}$ Latinos/as participate in the paradigm by engaging in racism against Blacks or darker-skinned members of Latino/a communities. Current events belie, however, Morrison's notion of American Blacks as "the real aliens." Mexican and other Latino/a and Asian aliens have become targets of state and federal legislation denying them medical and educational resources. ${ }^{80}$ The legislative attack on entitlement programs and affirmative action programs is an attack on Blacks, Latinos/as and Asians..$^{81}$

(1986); Charles J. McClain, In Search of Equality: The Chinese Struggle against Discrimination in Nineteenth-Century America (1994).

73. WEST, supra note 57, at 27.

74. Cf. Toni Morrison, On the Backs of Blacks, reprinted in ARGUING IMMIGRATION 97 (Nicolaus Mills ed., 1994).

75. See id.

76. Id.

77. Id.

78. Id. at 98 .

79. See, e.g., Studs Terkel, Race: How Blacks and Whites Think and Feel About an AMERICAN Obsession 11 (1992) (quoting Dr. Kenneth B. Clark: "One thing white immigrant groups could do in America was to believe they were moving upward because the blacks were always there: down below.... The Poles, Jews, Italians, and Irish could all get togetherr in their hostility to the blacks. It has become another aspect of the democratic creed.").

80. See generally IMMIGRANTS OUT!, supra note 54.

81. See generally id. 
In Cornel West's writing, we see the influence of the Black/White binary paradigm from the point of view of a leading Black writer on race. His view shares points in common with Andrew Hacker's. Both agree on the concepts of White and Black Americas (the "two nations"), and both focus exclusive attention on the relationship between Blacks and Whites, although they describe the nature of this relationship in very different terms. Both writers seem indifferent towards the history and conditions experienced by other non-White, non-Black groups. While Hacker unrealistically views all non-Blacks as aspiring immigrants on the path to assimilation with Whites, West, like Morrison, views nonBlack groups with suspicion. Morrison, in particular, seems to accept Hacker's view that all non-Blacks are (or will be) the enemies of Blacks as they Americanize and assimilate.

Taken together, these views pose serious problems for Latinos/as. Viewing Latinos/as as aspiring immigrants is, in most cases, a deeply flawed view, for two reasons. First, Mexican Americans, Puerto Ricans, and United States-born Cuban Americans, are not immigrants. Mexicans occupied the Southwest long before the United States ever found them. Second, this utopian view of immigrant assimilation takes no account of the systemic racism which afflicts Mexican Americans and Puerto Ricans. The utopian view serves White writers like Hacker because they can perpetuate the view that the United States has only a single race problem-the traditional binary problem of the White relationship with Blacks-rather than a more complex set of racisms that, if recognized, would demonstrate that racism is much more systemic and pervasive than Whites usually admit.

The suspicious view of immigrants and other non-White people, as articulated by West and Morrison, is flawed in similar ways. Again, viewing all non-Black minorities as aspiring immigrants, on their way to whiteness, negates both history and the deep-seated racism faced by many Latinos/as. ${ }^{82}$ Yet this view allows some Black writers to see Blacks as uniquely victimized by racism. Excessive distrust of Latinos/as and other non-Whites impairs the ability of all non-White people burdened by racism to form useful coalitions to oppose racism.

One can thus discern how the binary paradigm interferes with liberation and equality. If Latinos/as and Asian Americans are presumed to be White (or quasi-White) by both White writers and Black writers (a presumption not borne out in the lived experience of most Latinos/as

82. See infra Part III (discussing the history of Mexican-American struggle against segregated schools in California and Texas). 
and Asians), then our claims to justice will not be heard nor acknowledged. Whites can ignore our claims to justice, since we are not Black and therefore are not subject to real racism. And Blacks can ignore our claims, since we are presumed to be aspiring to and acquiring Whiteness, and therefore we are not subject to real racism. Latinos/as do not fit the boxes supplied by the paradigm.

\section{Three Decades of Books on White Racism}

There are at least three scholarly books titled White Racism. These books, each focusing only on White racism as it affects Blacks, demonstrate the remarkable continuity and power of the Black/White binary paradigm across a span of twenty-five years (and counting). They also demonstrate Kuhn's notion of "normal science" as the activity of paradigm elaboration and development. ${ }^{83}$ The "normal science" of scholarly inquiry on White racism consists of fact-gathering (on White racism and the experience of Blackness) and paradigm elaboration (progressively more sophisticated and detailed analysis of White oppression of Blacks).

White Racism: Its History, Pathology and Practice, edited by Barry N. Schwartz and Robert Disch, appeared in $1970 .{ }^{84}$ It is a wide-ranging and instructive collection of essays, most of which were originally published in the $1960 \mathrm{~s}$, on White racism and the experience of being Black in the United States. White Racism, by psychoanalyst Joel Kovel, was first published in 1970 and then a new edition, with an extensive new preface, was published in $1984 .{ }^{85}$ Finally, Joe Feagin and Hernan Vera published White Racism, a study of contemporary racism, in $1995 .^{86}$

These books are all innovative in their focus on White racism, which all of the authors consider to be the real racism problem. While many other books on race tend to focus on Blacks as "the race problem," 87 these books focus on those with the power to create and enforce racism, White people. Despite the pathbreaking nature of the Kovel and Feagin and Vera books, their analysis of White racism is limited to its deployment against Blacks.

The title of each of these three books, White Racism, suggests a claim to universality of coverage and explanation without qualifications.

83. See KuHN, supra note 4, at 23-30.

84. White Racism: Its History, Pathology and Practice (Barty N. Schwartz \& Robert Disch eds., 1970) [hereinafter Schwartz \& Disch].

85. JOEL KOVEL, White RACISM: A PSYCHOHISTORY (1984).

86. FEAGIN \& VeRA, supra note 28.

87. See WEST, supra note 57 , at 2-3. 
Yet all of the books focus only on the racism of Whites toward Blacks. By claiming to discuss the full scope of White racism in their titles, yet analyzing only the racism of Whites toward Blacks, these books all fit within, and help re-create, the Black/White binary paradigm. They confirm the pervasive view that racism is suffered solely by Blacks. To be more accurate in describing their limited scope, such books should be titled "White Racism Against Blacks."

Schwartz and Disch's White Racism features a sixty-six page introduction that covers the relationship between Whites and Blacks spanning biblical and classical literature, the early American period, and more recent events in Black and White racial history. ${ }^{88}$ There is no mention of Chicanos/as or Latinos/as, only a brief mention of Native Americans, ${ }^{89}$ and only a single reference to the Japanese-American internment. ${ }^{90}$ The introduction contains only isolated references to "blacks and other nonwhites," "other minority groups," and "leaders of minority groups." These sporadic and unclear acknowledgments of "other minority groups" encourage the reader to gloss over their existence.

While Schwartz and Disch's White Racism demonstrates the Black/White paradigm in the 1960s, Joel Kovel's White Racism demonstrates both continuing adherence to the basic paradigm and an elaboration and refining of the paradigm in the 1970s and 1980s. Kovel's book elaborates the paradigm by applying psychoanalytic theory to the understanding of White racism.

Kovel's 1984 preface demonstrates continuing adherence to the Black/White binary conception of race..$^{92}$ The preface presents a broad array of statistical evidence showing the disparities between Blacks and Whites in various arenas. In its discussion of White racism, the preface features only stories of Black integration and violence against Blacks. The Black experience in America is somehow taken as representative of the whole complicated universe of race relations. ${ }^{93}$ Kovel illustrates his binary conception of Black/White race relations. He writes about White racism that "its primary object is the black, for the basic reason that it arose out of the enslavement of millions of Africans over three

88. See Schwartz \& Disch, supra note 84, at 1-66.

89. See id. at 41-43.

90. See id. at 47 .

91. See id. at $1,3,45,65$.

92. See Kovel, supra note 85 , at ix-lvi.

93. See, e.g., id. at $\mathrm{xxxiii}$. 
centuries. Our racism is white because our social production came so extensively out of enslaved black bodies."

In the 1970 introduction to his book, Kovel reveals a similar binary understanding of race relations and racism. Because of its overriding importance, Kovel focuses on the "course of white-black racism in America." ${ }^{\prime 95}$ Furthermore, Kovel describes the need to consult a range of works by Black authors to get a sense of the Black experience for a "full-scale assessment of the entire historical problem of racism." Kovel points out, accurately, that "this culture is obsessed with whiteblack racism."

Consistent with his paradigmatic understanding of race and racism, and like the books discussed earlier, other non-White groups are entirely marginalized and virtually nonexistent in Kovel's treatment. Kovel's 1984 preface only mentions Latinos twice, once parenthetically ("black (and Latino)")", and "other ... minorities" once. ${ }^{99}$ The rest of his book deals exclusively with White racism and the symbolic meanings of Whiteness and Blackness produced by racism. I found, in the body of the book, only a single reference to "ethnic origin," with no further explanation or commentary on the relevance of ethnic origin to his argument. ${ }^{100}$

Beyond demonstrating the continuing power of the Black/White binary paradigm in structuring racial thought and understanding, Kovel's book also provides an example of "normal science" and paradigm elaboration. Normal science involves scholarly investigations and research within the bounds defined by the paradigm. ${ }^{101}$ Paradigm elaboration involves explication of the paradigm with different, usually increasing, degrees of depth and sophistication.

Kovel elaborates on the Black/White binary paradigm by using psychoanalytic concepts of "the Other" and the construction of the self to explore the conscious and unconscious symbolic meanings of Blackness and Whiteness. Kovel states that "blackness is Otherness." 102 Kovel also describes the role of Black others in the construction of the White self: "The racist relation is one... in which the white self is

94. Id. at xxxvii.

95. Id. at 10.

96. Id. at 11 (emphasis added).

97. Id. at 53.

98. Id. at xvii, xxviii.

99. Id. at $x x \times v i i$.

100. Id. at 231.

101. See supra Part 1.

102. Kovel, supra note 85 , at $\mathrm{xxxviii.}$ 
created out of the violation of the black self, through its inclusion and degradation. Racism degrades the Other to constitute the dominant self, and its social order." 103

Kovel also explores in psychoanalytic terms the symbolic meanings and fantasies associated with racial Blackness and Whiteness. He discusses how Blacks came to represent the devil, in the now-familiar terms of the binary paradigm: "Blackness was the nuclear fantasy, and joined with its polar cognate, whiteness, the two being symbolic abstractions of a human vision of a world that in reality has no such absolutes." 104 Kovel also describes the opposing moral values assigned to the binary structure of Black and White:

Racism abstracts the color of the living body into non-colors of extreme value, black and white. Within this organization, black represents the shade of evil, the devil's aspect, night, separation, loneliness, sin, dirt, excrement, the inside of the body; and white represents the mark of good, the token of innocence, purity, cleanliness, spirituality, virtue, hope. But is this extreme polarity, the one all bad, the other all good, really so simple? Rather than the symbolic polarity, which is, after all, arbitrary, is it not the activity that generates this polarity which counts-the psychohistorical effort by which blackness and whiteness are generated as figments of value and imposed upon the world? ${ }^{105}$

Kovel recognizes, then, that the arbitrary assignment of moral values to Whiteness and Blackness is contingent on particular psychohistorical events. Thus he recognizes that, in contemporary critical terms, racial meanings are socially constructed. ${ }^{106}$

However, despite the sophistication of his psychoanalytic deconstruction of Blackness and Whiteness and his rich exploration of their symbolic meanings and functions, his inquiry into White racism is entirely bounded by the Black/White binary paradigm. While Kovel adds to our understanding of the Black-White relationship through the application of psychoanalysis, he also reifies the understanding that it is only that relationship that is worth studying. In the saine stroke, he elaborates upon and rigidifies the binary paradigm. This rigidity is destructive with respect to non-Black, non-White peoples, who are rendered entirely nonexistent because of the paradigmatic boundaries of his analysis. If, for a moment, we take a broader view, is it really plausible to

103. Id. at xliii.

104. Id. at 62 .

105. Id. at 232 (emphasis added).

106. See generally Haney López, supra note 27 . 
believe that only Blacks, and not Indians, Mexican Americans and Asians, have important symbolic meanings and functions for White and Black Americans, as well as for each other? ${ }^{107}$ The practice of "normal" racial science and paradigm elaboration yields precisely this implausible result: there is little or no understanding of the symbolic constellation formed by the many constituent American racial groups.

Feagin and Vera's White Racism, published in 1995, represents a further elaboration and reification of the Black/White paradigm for the 1990s. The authors depart from prior literature and elaborate on the extant paradigm by applying their theory that "white racism is a system of institutionalized human waste that this society cannot afford." 108 According to the authors, White racism results in enormous costs in human talent and energy for both Blacks and Whites. While the costs to minority-group victims of racism are "direct, heavy, and immediately painful," the costs to Whites are "indirect and seldom recognized."109 The authors attempt to show these costs to participants in White-againstBlack racism through a series of contemporary case studies that update and elaborate the paradigm.

As with the previous books on White racism, however, Feagin and Vera make only sporadic references to unnamed "other people of color." The reader is left to wonder, again, about the relationship between White racism against African Americans and White racism against ambiguous "other people of color." 110 The entire book is organized around the Black/White paradigm, thereby reasserting the importance of understanding all race through an examination of only this relationship.

To their credit, and unlike the earlier White Racism books, the authors are explicit in the use of the Black/White relationship as a paradigm for understanding other racisms: "[W]e focus centrally on white racism as it targets and exploits African Americans because that racism is an archetype for other subsequent patterns of white treatment of

107. Of course this belief is not plausible. Indeed, in my discussion above, a tiny portion of the symbolic meaning of Latinos/as and immigrants for Blacks became more clear. Both Latinos/as and immigrant groups are deemed unworthy of trust and are seen by many Blacks as depriving Blacks of opportunities and livelihood which would otherwise be theirs. See supra text accompanying notes 57 77.

108. FEAGIN \& VERA, supra note 28, at 2.

109. Id.

110. It may be misleading to focus on only one of Professor Feagin's inany fine books. From my personal knowledge, Professors Feagin and Vera are deeply committed to the antiracist struggle and to equality for all oppressed groups. Professor Feagin has written with sensitivity and particularity about many racial and ethnic groups, including Latinos/as, in his excellent leading textbook. See generally Joe R. Feagin \& Clairece Booher Feagin, Racial and Ethinic Relations 258-337 (4th ed. 1993). 
people of color."111 Furthermore, the authors argue that African Americans are appropriately a "central point of reference," 112 because other racisms cannot be understood without a focus on the Black-White relationship:

White-on-black racism is thus a-if not the-crucial paradigmatic case of racism historically and in the present. Other types of white-on-minority racism are very important, and there is a great need to eradicate them all. Yet we believe that they cannot be adequately understood until we understand deeply the character and history of white racism as it has targeted African Americans. ${ }^{113}$

The very conscious recognition and use of White-against-Black racism as a paradigm, while a significant step towards clarity in the intellectual tools we use to understand racism, also has its limitations. Feagin and Vera assert that deeper inquiry into the paradigmatic relationship is a necessary condition for understanding the racism experienced by any other racialized American minority group. They assert, in essence, that normal, paradigmatic research is the key to solving pervasive, multiple racisms. The Black/White paradigm, thus asserted, may become an even more unyielding and impenetrable form of study and discourse than it was before. All other racial studies must be dependent upon the results of "normal" science.

In my view, Feagin and Vera are wrong in asserting that a deeper understanding of the Black-White relationship will necessarily promote understanding of the particularities of other racisms. I agree with Feagin and Vera that an understanding of White-against-Black racism may be helpful in understanding the deployment of racism against other non-Whites, for example in understanding the persistent use and tolerance of segregation against non-White peoples. However, an exclusive focus on the Black-White relationship, and the concomitant margin-alization of "other people of color," can operate to prevent understanding of other racisms and to obscure their particular operation. For example, the attribution of foreignness to Latinos/as and Asian Americans, or discrimination on the basis of language or accent, are powerful dynamics as played out against these groups that do not

111. FEAGin \& VeRA, supra note 28 , at $\mathrm{xi}$.

112. Id.

113. Id. at xii. 
appear to be as significant in the dynamics of White-against-Black racism. ${ }^{114}$

Thus the White Racism books, spanning three decades, all reproduce and reify the same Black/White binary paradigm of race. In Kuhn's terminology, these books represent the "normal science" of scholarship on White racism, consisting of exploration and elaboration of the Black/White binary paradigm. Only the most recent White Racism book, by Feagin and Vera, makes explicit the Black-White paradigm and its key assumption: that somehow a deeper understanding of the Black-White relationship will yield understanding of the racism experienced by Latinos/as, Asian Americans, Native Americans, and other racialized American groups.

After three decades of books on White Racism focusing only on racism against Blacks, one can fairly ask how much anyone understands about racism against Latinos/as and the particular forms that such racism takes? The obvious answer is "not very much." For example, one could study the American Black/White relationship forever and never understand the language and accent discrimination faced by many Latinos/as and Asian Americans. ${ }^{115}$ Today Latinos/as can be fired from their jobs merely for speaking Spanish in the workplace, ${ }^{116}$ and Asian Americans can be passed over for hire because their accent is not quite right. ${ }^{117}$ Despite nominal statutory protection from such discrimination under the "national origin" provisions of Title VII, the courts remain almost uniformly indifferent and find no actionable discrimination in such cases.

The reason for this indifference is that such discrimination does not fit the Black/White binary paradigm of race discrimination. Redressing the particular forms of discrimination experienced by Latinos/as, Asian

114. See Juan F. Perea, Ethnicity and Prejudice: Reevaluating National Origin Discrintination Under Title VII, 35 WM. \& MARY L. Rev. 805, 826-31, 853-57 (1994); Robert S. Chang, A Meditation on Borders, in lmmigrants Out! supra note 54; see also Neil Gotanda, "Other NonWhites" in American Legal History: A Review of Justice at War, 85 CoLum. L. Rev. 1186 (1985).

115. Interestingly, the current controversy over Ebonics may demonstrate how breaking the binary paradigm by incorporating concepts of language diserimination from sources outside of the traditional binary paradigm can provide insight that will help unravel the ways in which Blacks are discriminated against because of language.

116. See, e.g., Garcia v. Spun Steak Co., 998 F.2d 1480 (9th Cir. 1993) (holding that employer's requirement that bilingual employees speak only English while on the job does not violate Title VIl).

117. See, e.g., Fragante v. City and County of Honolulu, 888 F.2d 591 (9th Cir. 1989) (holding that an adverse employment decision may be predicated on an individual's accent when it interferes materially with job performance and not violate Title VII). For an excellent discussion of this and other cases and accent diserimination generally, see also Mari J. Matsuda, Voices of America: Accent Antidiscrimination Law, and a Jurisprudence for the Lost Reconstruction, 100 YALE L.J. 1329 (1991). 
Americans, Native Americans and other racialized groups requires very careful inquiry into the particular histories of these groups and the forms of discrimination they have experienced. But recognition of the importance and particularity of groups other than Blacks and Whites requires inquiry well beyond the paradigm, inquiry beyond the current bounds of "normal science" and research. From the point of view of LatCrit studies, then, the issue becomes why there is such a rigid and unyielding commitment to an exclusively Black-White understanding of race that is clearly underinclusive and inaccurate.

Robert Blauner, writing in 1972, recognized and forcefully criticized the Black/White binary paradigm. ${ }^{118}$ His critique may be applied generally to scholars who have embraced and reified the binary paradigm while ignoring greater actual racial complexity. Blauner noted that Mexican Americans cannot be understood within the confines of the Black/White paradigm nor the model of immigration and assimilation:

The encounter between Mexican-Americans and the United States is sui generis, it cannot be forced into the ethnic model of immigration-assimilation nor into the category of black/white relations. That is why Chicanos, painfully aware of their unique history, resent and resist being classified, interpreted, or "understood" through analogs with the Afro-American. ${ }^{19}$

\section{III}

Further Paradigm Productions and Ways of Revision: Constitutional LaW TEXtbOOKS AND Legal HistoRY

One of Kuhn's insights about paradigms is their power to define relevance and so to define the scope of fact-gathering..$^{20}$ One of the most striking results of the Black/White binary paradigm is that it limits the scope of relevant facts that are deemed important in research and teaching about this country's racial history. Within the paradigm, the only facts and histories that matter are those regarding Whites and Blacks. Therefore, virtually the only stories we ever learn about civil rights are stories about Blacks and Whites struggling over civil rights for Blacks.

118. See Robert Blauner, Racial Oppression in America 163-66 (1972).

119. Id. at 175 .

120. See KuHN, supra note 4, at 25. Regarding the normal scope of factual investigation, Kuhn states, "First is that class of facts that the paradigm has shown to be particularly revealing of the nature of things." Id. 
This Section will show how a leading constitutional law text, like scholarly and popular literature on race, has adopted and reproduced the Black/White binary paradigm, promulgating a linear progression of the evolution of civil rights history based on the Black struggle for civil rights. As Kuhn described with regard to scientific texts, however, a linear, Black/White version of civil rights history can only be achieved by truncating and distorting history. ${ }^{121}$ As Kuhn wrote, events "that will not fit the box are often not seen at all."122

In this Section, I will show how relevant Mexican-American legal history is entirely omitted in the paradigmatic telling of the civil rights story. This omission demonstrates the inadequacy of the existing paradigm of race and the truncation of history for the sake of the paradigm. This truncated legal history also shows how existing paradigms must be changed and expanded to provide a more accurate sense of past and present reality.

Stone, Seidman, Sunstein \& Tushnet's Constitutional Law ${ }^{123}$ (the Stone book) is a good example of the use of the Black/White binary paradigm. The book is explicit about its use of the binary paradigm and its controlling influence on constitutional law. Indeed, the authors go so far as to conflate "Black" with race. Their first section under Equality and the Constitution is Race and the Constitution, by which the authors clearly mean the Black race:

This section traces the evolution of constitutional doctrine concerning discrimination against blacks....

[I]n one form or another, the controversy about the legal status of blacks has been central to U.S. politics since the founding of the republic.... [C]onsider the extent to which judicial decisions have shaped that controversy and the extent to which they have been shaped by it.

[T] he Court's analysis of discrimination against blacks has served as a prototype for the development of other constitutional doctrines.... [C]ontroversies over school segregation, racial discrimination in access to political power, and "affirmative action" have shaped attitudes toward the proper scope of constitutional protection for minorities generally. To what extent is our experience with discrimination against blacks

121. See id. at 136-39.

122. Id. at 24.

123. Geoffery R. Stone et al., Constitutional Law (2d ed. 1991). 
generalizable? Have the special problems faced by black Americans distorted constitutional law? ${ }^{124}$

The authors thus consciously use the evolution of equality doctrines through the Black struggle for civil rights as their basic paradigm for equality under the Constitution.

Legal history provides ample support for the authors' contention that struggles over the legal status of Blacks have been central in shaping the Constitution and the Supreme Court's decisions on race and equality. All the civil rights enactments and court decisions deemed major in this area have sought to redress harms to Blacks. ${ }^{125}$ The Thirteenth and Fifteenth Amendments abolished slavery and race discrimination in voting, respectively. ${ }^{126}$ The first sentence of the Fourteenth Amendment established federal and state citizenship for Blacks, reversing the Dred Scott decision. ${ }^{127}$ The Equal Protection Clause of the Fourteenth Amendment was enacted principally to protect the civil equality of the newly freed slaves from hostile state action. ${ }^{128}$ Plessy v. Ferguson ${ }^{129}$ sanctioned the separate and unequal regimes established by Jim Crow laws throughout the South. Brown v. Board of Education $^{130}$ abolished separate but equal schools and was widely understood as a vindication of Black equality interests. The Civil Rights Act of 1964, as well, was passed as an attempt to establish equal treatment for Blacks in crucial social, educational and economic institutions. ${ }^{131}$

The casebook authors explicitly recognize that constitutional protection against discrimination on grounds other than race exists purely

124. Id. at 471-72 (emphasis added).

125. Since the most important civil rights laws, constitutional provisions and Supreme Court decisions have attempted, albeit unsuccessfully, to redress White injustice inflicted upon Blacks, Blacks can properly see themselves as the intended beneficiaries of most civil rights enactments. And Whites can see themselves (falsely) as the altruistic, beneficent grantors of civil rights who have corrected past injustices. Derrick Bell's apt commentary on this sort of reaction by Whites is particularly insightful. See DerRICK BeLl, Race, RaCism AND AMERICAN LAw 12 (3rd ed. 1992) (civil rights "relief is viewed as proof that society is indeed just, and that eventually all racial injustices will be recognized and remedied"); see also James Baldwin, The Fire Next Time 10001 (1963).

126. See U.S. CONST. amend. XIII, XV.

127. See U.S. CONST. amend. XIV, §1.

128. See The Slaughterhouse Cases, 83 U.S. (16 Wall.) 36 (1873); Strauder v. West Virginia, 100 U.S. 303 (1879); see generally RAOUL BERGER, GOVERNMENT BY JUdiciaRY (1964).

129. 163 U.S. 537 (1896).

130. 347 U.S. 483 (1954).

131. See generally U.S. EQUAL EMPLOYMENT OPPORTUNITY COMM'N, LEgISLATIVE HISTORY of Titles VII AND IX OF THE Civil Rights ACT OF 1964 (1968) (edited compilation of legislative documents); see also Perea, supra note 114, at 816-21 (1994). 
by analogy. ${ }^{132}$ Yet they also seem to recognize possible limits of the analogies to race upon which equal protection for subordinated groups other than Blacks must rest. They ask essential questions: to what extent is the Black experience generalizable? To what extent has that experience distorted constitutional law? ${ }^{133}$ Alternatively, to what extent has that experience determined the meaning of constitutional law? Despite the authors' apparent recognition of the limits of analogies to Blacks, the Stone book is disappointing for its failure to answer these questions and for its exclusive focus on the Black experience in the context of race.

The linear, paradigmatic version of the story of civil rights and equality is a story of an exclusively Black struggle for equality and a gradual, progressive White concession to Black demands voiced in the courts and on the streets. This is the version presented by the Stone book. The book describes the NAACP's legal strategy and the familiar cases litigated by the NAACP, including Missouri ex rel Gaines $v$. Canada, ${ }^{134}$ Sipuel $v$. Board of Regents, ${ }^{135}$ Sweatt v. Painter, ${ }^{136}$ and McLaurin v. Oklahoma State Regents, ${ }^{137}$ all of which culminate in Brown v. Board of Education. ${ }^{138}$

In order to tell this linear story of Black civil rights, the authors of the Stone book engage in a numbing truncation of history. For example, despite over forty pages of material on school desegregation, there is not a single mention of Latino/a segregation and desegregation as significant issues in American legal history. ${ }^{139}$ By excluding all material on Latino/a segregation and desegregation, students are left with the misimpression that such segregation never existed or was never a significant problem.

On the contrary, Mexican Americans suffered from a very long tradition of segregation in public schools throughout the Southwest, both before and after the Supreme Court's decision in Brown v. Board

132. See StONE ET AL., supra note 123 , at 688-92, 718-19, 724-25.

133. See id. at 471-72.

134. 305 U.S. 337 (1938).

135. 332 U.S. 631 (1948).

136. 339 U.S. 629 (1950).

137. 339 U.S. 637 (1950).

138. 347 U.S. 483 (1954); see STONE ET AL., supra note 123, at 493-99; see also MARK V. Tushnet, Making Civil Rights Law 116-31 (1994).

139. See StONE ET AL., supra note 123 , at $488-532$. 
of Education. ${ }^{140}$ Carey McWilliams described the segregated schools in Westminister, Orange County, California:

There are two schools in Westminister: a handsomely equipped school with green lawns and shrubs for the Anglo-Americans; and a Mexican school whose meager equipment matches the inelegance of its surroundings. It was not the discrepancy between the two schools, however, that annoyed Gonzalo Méndez. Rather it was the fact, so he said, that he didn't like the idea of his Sylvia, Gonzalo Jr., and Gerónimo, growing up with hatred in their hearts for the children who went to the beautiful school. In the nearby community of El Modeno, the two schools were side by side; but the Mexican youngsters were always served lunch at a different hour from the Anglo-American students. ${ }^{141}$

Moreover, Chicanos played an important role in fighting and ultimately overturning school segregation. In Mendez v. Westminister School District of Orange County, ${ }^{142}$ Gonzalo Mendez and several other Mexican-American parents challenged the long-standing and pervasive segregation of Mexican-American children in Orange County. ${ }^{143}$ California's segregation statutes permitted school boards to establish separate schools for "Indian children ... and for children of Chinese, Japanese, or Mongolian parentage."144 Despite the absence of Mexican Americans from the statutory list, the parties "admitted that segregation per se is practiced in the above-mentioned school districts as the Spanish-speaking children enter school life and as they advance through the grades in the respective school districts."145 One commentator found it ironic that "the Code did not mention the group that was most commonly segregated by 1945 : children of Mexican descent."146

One of the State's arguments in Mendez was that the Supreme Court had authorized the segregation of the races under the "separate but equal" doctrine of Plessy v. Ferguson. ${ }^{147}$ District Judge McCormick

140. See Martinez, supra note 39, at 577-84 (1994); see also Gary A. Greenfield \& Don B. Kates, Jr., Mexican Americans, Racial Discrimination, and the Civil Rights Act of 1866, 63 CAL1F. L. Rev. 662, 711-15 (1975); Mario T. García, Mexican AMERICANS 53-59 (1989).

141. Carey MCWilliams, North from Mexico 280-81 (1949).

142. 64 F. Supp. 544 (S.D. Cal. 1946), aff'd, 161 F.2d 774 (9th Cir. 1947).

143. See Charles Wollenberg, Mendez v. Westminister: Race, Nationality and Segregation in California Schools, 53 CAL. HIST. Q. 317, 317 ("Separation of school children on grounds of race and nationality in California is almost as old as public education itself.").

144. Mendez, 64 F. Supp. at 548 n.5. For a description of school segregation against the Chinese in California, see Wollenberg, supra note 143 , at 318 .

145. Mendez, 64 F. Supp. at 546.

146. See Wollenberg, supra note 143 , at 318.

147. See id. at 326 . 
found that the physical facilities, teachers and curricula of the segregated school for Mexican children were "identical and in some respects superior to those in the other schools."148 Accordingly, unlike many of the pre-Brown Black segregation cases, this case did not focus on the inequality of separate facilities, but rather on the inherent evil of statesponsored segregation itself.

After concluding that segregation of Mexican-American children was inconsistent with California's Education Code, ${ }^{149}$ Judge McCormick considered the federal constitutional question. Relyiug on a prescient interpretation of equal protection and on the stigmatizing effects of segregation on children subject to it, he concluded that California's segregation of Mexican-American pupils violated the Equal Protection Clause. The judge wrote:

'The equal protection of the laws' pertaining to the public school system in California is not provided by furnishing in separate schools the same technical facilities, text books and courses of instruction to children of Mexican ancestry that are available to the other public school children regardless of their ancestry. A paramount requisite in the American system of public education is social equality. It must be open to all children by unified school association regardless of lineage..$^{150}$

In this remarkable paragraph, the court rejects the entire underpinning of the Supreme Court's opinion in Plessy v. Ferguson ${ }^{151}$ and foreshadows the reasoning of the Court in Brown v. Board of Education. ${ }^{152}$ Where Plessy had reified segregation by disclaiming the Court's power to act to remedy social inequality, ${ }^{133}$ the Mendez opinion conveys a powerfully different understanding of equality that ultimately prevails in Brown.

The Mendez court also anticipated Brown, aud rejected Plessy, ${ }^{154}$ in its understanding of the role of public education and the stigmatizing meaning and purpose of segregation:

148. Mendez, 64 F. Supp. at 546.

149. See id. at 548 .

150. Id. at 549 (emphasis added).

151. 163 U.S. 537 (1896).

152. 347 U.S. 483 (1954).

153. See Plessy, 163 U.S. at 544 (the Fourteenth Amendment "could not have been intended to abolish distinctions based upon color, or to enforce social, as distinguished from political equality, or a commingling of the two races upon terms unsatisfactory to either").

154. In Plessy, the Court stated that enforced segregation "do[es] not necessarily imply the inferiority of either race to the other." Id. Judge McCormick's opinion in Mendez clearly contradicts this assumption. 
The evidence clearly shows that Spanish-speaking children are retarded in learning English by lack of exposure to its use because of segregation, and that commingling of the entire student body instills and develops a common cultural attitude among the school children which is imperative for the perpetuation of American institutions and ideals. It is also established by the record that the methods of segregation prevalent in the defendant school districts foster antagonisms in the children and suggest inferiority among them where none exists. ${ }^{155}$

In Mendez, Judge McCormick crafted an opinion whose interpretation of the meaning of equal protection foreshadowed closely the reasoning in Brown. ${ }^{156}$ The United States Court of Appeals for the Ninth Circuit upheld Judge McCormick's decision on narrower, statutory grounds. ${ }^{157}$

Legal scholars and the general public recognized the importance of the Mendez decision. ${ }^{158}$ A Note on the Mendez case in The Yale Law Journal commented, regarding Plessy's "separate but equal" doctrine, that:

a recent district Court decision [Mendez] . . . has questioned the basic assumption of the Plessy case and may portend a complete reversal of the doctrine. ... Modern sociological and psychological studies lend much support to the District Court's views.

155. Mendez, 64 F. Supp. at 549 (emphasis added).

156. Compare the above quoted language from Mendez with the famous language from Brown: [Education] is the very foundation of good citizenship. Today it is a principal instrument in awakening the child to cultural values, in preparing him for later professional training, and in helping him to adjust normally to his environment.

To separate [children in grade and high schools] from others of similar age and qualifications solely because of their race generates a feeling of inferiority as to their status in the community that may affect their hearts and minds in a way unlikely ever to be undone.

Brown, 347 U.S. at 493-94; see also Wollenberg, supra note 143, at 329 ("[M]uch of the social and educational theory expressed by Judge McCormick anticipated Earl Warren's historic opinion in the Brown case.").

157. Westminister School Dist. v. Mendez, 161 F.2d 774, 780-81 (9th Cir. 1947). The court of appeals opinion does not discuss the substantive scope of equal protection in the way the district court did. Indeed, the court of appeals contradicted the district court's equal protection holding by saying, "for the argument," that California could legally enact a statute authorizing the segregation of Mexican-American children. See id. at 781. Only Judge Denman, concurring, describes with outrage California's history of segregation against Mexican Americans, mentioning López $v$. Seccombe, 71 F. Supp. 769 (S.D. Cal. 1944), discussed infra at notes 173-177 and accompanying text, as both example and controlling precedent for the decision in Westminister. See id. at 781-82 (Denman, J., concurring).

158. See Garcfa, supra note 140, at 56-57; Gonzalez, supra note 39, at 153-56 ("Mendez immediatcly gained widespread attention from legal scholars who quickly recognized the historical significance of the court decision."); Wollenberg, supra note 143, at 327-29. 
A dual school system, even if "equal facilities" were ever in fact provided, does imply social inferiority. ${ }^{159}$

Another Note on the Mendez case, in Columbia Law Review, commented on its significance:

The segregation of races has not previously been considered a denial of equal protection so long as equal facilities were made available to the members of both groups....

Attacks on segregation based on the equal protection clause of the 14th Amendment have been equally unsuccessful. If the physical facilities available to each group are substantially equal, the courts have followed the traditional view that the humiliation engendered by relegation to an inferior social status is not in itself indicative of discrimination. The court in the instant case breaks sharply with this approach and finds that the 14th Amendment requires "social equality" rather than equal facilities. ${ }^{160}$

Both of these notes, but particularly the note in Yale Law Journal, recognize the importance of $M$ endez in furthering the cause of racial justice and desegregation for Blacks. ${ }^{161}$ On appeal, Thurgood Marshall, Robert L. Carter, and Loren Miller filed an amicus brief on behalf of the NAACP urging the desegregation of Orange County's schools. ${ }^{162}$ Robert L. Carter, Assistant Special Counsel of the NAACP, apparently used this brief as a dry run of the argument that segregation was unconstitutional per se. ${ }^{163}$ Carter noted that cases pending in Oklahoma, Texas, Louisiana and South Carolina involving segregated schools "may require a Supreme Court ruling in the near future on the constitutional issue of the Mendez case."164 The NAACP's efforts in support of the Mexican-American plaintiffs in these cases provide an example of early coalition between Blacks and Latinos/as to defeat White racism and Jim Crow as inflicted upon Latinos/as. Mexican-American plaintiffs

159. Note, Segregation in the Public Schools-A Violation of "Equal Protection of the Laws," 56 YALE. L.J. 1059, 1060 (1947).

160. Note, Segregation in Schools as a Violation of the XIVth Amendment, 47 ColuM. L. REV. 325, 326-27 (1947).

161. See Note, supra note 159 , at 1060-67 (reviewing studies establishing ncgative effects of segregation on blacks and arguing for reversal of Plessy).

162. See Westminister, 161 F.2d at 775.

163. See RiChARD KIUGER, Simple JuSTice $399-400$ (1975). I would think that the authors of the Stone book would find this "dry run" of the argument to overrule Plessy as significant in their narrative of the NAACP's litigation strategy. Their narrative, however, neglects to mention the Westminister case and the NAACP's role as amicus in the case.

164. Note, supra note I59, at $1060 \mathrm{n} .12$ (communication to Yale Lonv Journal from Robert L. Carter, Ass't Special CounseI NAACP). 
also sued to desegregate the Texas schools in the Delgado v. Bastrop ${ }^{165}$ litigation, the first step leading to the defeat of school segregation in Texas. $^{166}$

Significantly, it was the Mendez decision that led to California's repeal of its school segregation statutes. ${ }^{167}$ Then Governor Earl Warren signed legislation repealing California's segregation statutes on June 14, 1947. ${ }^{168}$ This was, of course, the same Earl Warren who, as Chief Justice of the United States, would later pen the opinions in Brown v. Board of Education ${ }^{169}$ and Hernandez v. Texas. ${ }^{170}$ The sequence of events following Mendez might have provided a clue about what was to come when school segregation reached the Supreme Court. ${ }^{171}$ The Stone book, like other constitutional law textbooks, ${ }^{172}$ omits entirely this significant portion of the history of desegregation.

Other segregation-era cases tell a powerful story of White racism against Mexican Americans and strong Mexican-American resistance in the courts. In Lopez $v$. Seccombe, ${ }^{173}$ for example, several leading Mexican-American and Puerto Rican citizens of San Bernardino, California, representing a class of 8000 Mexican Americans, sued officials of San Bernardino to gain simple access to a public park. ${ }^{174}$ All

165. Civil No. 388 (W.D. Tex. June 15, 1948) (unpublished order).

166. See Gonzalez, supra note 39, at 155.

167. See Wollenberg, supra note 143, at 329 ("The Mendez case also had repercussions in Sacramento. It focused attention on the issue of school segregation and on the California statutes still allowing such practices.").

168. See id.

169. 347 U.S. 483 (1954).

170. 347 U.S. 475 (1954) (discussed infra at nn. 178-195and accompanying text).

171. It is interesting to wonder to what extent Warren's awareness of the Mendez decision as Governor of California later eased his ability to decide Brown and Hernandez as he did.

172. Derrick Bell, Race, Racism and American LaW (3d. ed. 1992) is another important treatise on the legal and historical development of race relations. Its title, like those of the books on White racism, claims universality of subject and treatment. But also like the books on White racism, its subject matter is essentially circumscribed to "American racism initiated by whites against blacks." Jd. at xxiii. While Bell recognizes that other groups have been victimized by White racism and discusses some cases in the areas of voting rights and wealth discrimination affecting Latinos/as, see $i d$. at xxiii, his book discusses at any length only racism experienced by Blacks.

The same point that I have made regarding constitutional law texts applies generally to law review treatments of race, with few exceptions, most notably the present Symposium issue. Many law review symposium issues on race discuss only Black and White race and consider themselves complete. This has generally been the rule, with only recent and few exceptions.

173. 71 F. Supp. 769 (S.D. Cal. 1944).

174. See id. This lawsuit was brought in 1944 by Ignacio Lopez, head of the Spanish Department in the Office of Foreign Language, Division of War Information, the Reverend R.N. Nuñez, Catholic Priest and head of the San Bernardino parish of the Guadalupe Church, Eugenio Nogueroa, a veteran of the 76th Field Artillery, Third Division, U.S. Army, and Virginia Prado and Rafael Muñoz, two students and residents of San Bernardino. See id. at 770. 
persons of Mexican or Latin descent, including the plaintiffs, had "been excluded, barred and precluded" for several years from using a public park, playground, swimming pool, bathhouse and other facilities solely because of their Mexican and Puerto Rican ancestry. ${ }^{175}$ Apparently in response to contrary arguments by counsel for San Bernardino, the trial judge found it necessary to make a specific finding that the plaintiffs "are of clean and moral habits not suffering any disability, infectious disease, nor have they any physical or mental defect" that might justify the discrimination against them. ${ }^{176}$ The court concluded that segregation of San Bernardino's public park violated the Equal Protection Clause and issued a permanent injunction prohibiting the segregation of persons of Mexican and Latin ancestry. ${ }^{177}$

The Supreme Court finally considered discrimination against Mexican Americans in Hernandez v. Texas, ${ }^{178}$ decided two weeks before Brown v. Board of Education. In Jackson County, Texas, grand and petit jurors were chosen by jury commissioners sworn to "not knowingly select a grand juror they believe unfit or unqualified."179 The state agreed to a stipulation that qualified male Mexican-American freeholders who lived in Jackson County were fully qualified to serve on grand juries. ${ }^{180}$ Between six and seven percent of the freeholders in Jackson County, Texas were Mexican American, but not a single Mexican American had served on a Jackson County jury in the last 25 years. ${ }^{181}$ The Court concluded that "the result bespeaks discrimination, whether or not it was a conscious decision on the part of any individual jury commissioner." 182 Accordingly, the Court decided that the discriminatory application of ostensibly neutral jury selection procedures violated the Equal Protection Clause. ${ }^{183}$

The Hernandez decision is important in constitutional law for several reasons. It was the first case to recognize that Mexican Americans constitute a "cognizable minority group for equal protection purposes in areas where they are subject to local discrimination."184 The Warren

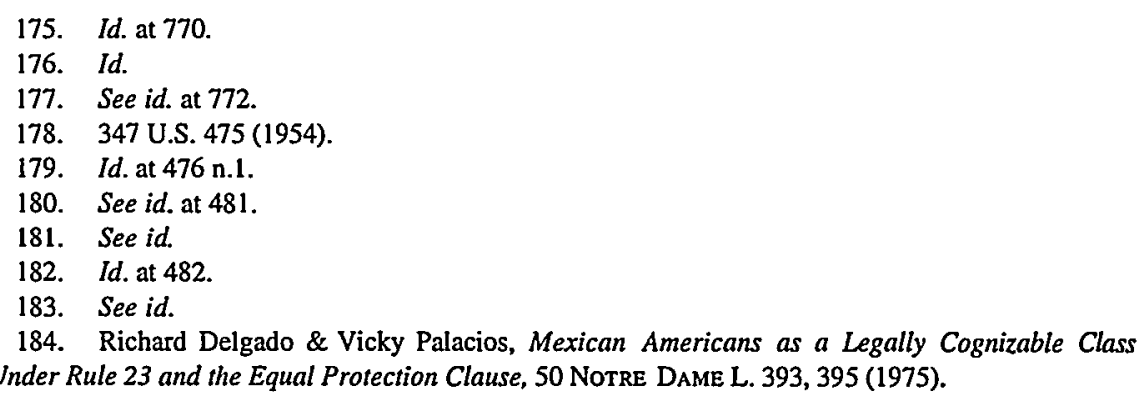


Court was able to transcend, at least to a limited extent, the Black/White binary paradigm. ${ }^{185}$ The Court wrote that the "Fourteenth Amendment is not directed solely against discrimination due to a 'two-class theory' - that is, based upon differences between 'white' and Negro."186

Second, like Yick Wo v. Hopkins ${ }^{187}$ and Gomillion v. Lightfoot, ${ }^{188}$ the Hernandez decision stands for the proposition that the discriminatory application of a neutrally worded standard against a minority defined by race and national origin (persons of Mexican ancestry) violates the Equal Protection Clause. Furthermore, the decision is tied directly to the Court's early interpretation of the Fourteenth Amendment in Strauder v. West Virginia. ${ }^{189}$ In Strauder, the Court declared that the statutory exclusion of Blacks from jury service violated the Equal Protection Clause. ${ }^{190}$ The Court also foresaw the eventual extension of equal protection doctrine to national origin classifications, a move finally accomplished in Hernandez. In Strauder, the Court wrote: "Nor if a law should be passed excluding all naturalized Celtic Irishmen, would there be any doubt of its inconsistency with the spirit of the amendment."191 Given these links to Strauder, the casebook authors should cite Hernandez, as well as the Yick Wo opinion, for the principle that they both articulate.

Finally, Hernandez is also important for the snapshot it gives of the application of Jim Crow laws against Mexican Americans in Texas and throughout the Southwest. Describing conditions faced by Mexican Americans in Jackson County, the Court wrote:

[T] he testimony of responsible officials and citizens contained the admission that residents of the community distinguished between "white" and "Mexican." The participation of persons of Mexican descent in business and community groups was shown to be slight. Until very recent times, children of Mexican descent were required to attend a segregated school for the first four grades. [Most of the children of Mexican descent left school by the fifth or sixth grade.] At least one restaurant in town prominently displayed a sign announcing "No Mexicans Served." On the courthouse grounds at the time of the hearing,

185. See id. at 395-96 (criticizing the Hernandez decision, 347 U.S. 475 (1954), for not recognizing Mexican Americans as a nationwide class subject to discrimination).

186. Hernandez, 347 U.S. at 478.

187. 118 U.S. $356(1886)$.

188. 364 U.S. 339 (1960).

189. 100 U.S. 303 (1879).

190. See id. at 310.

191. Id. at 308 . 
there were two men's toilets, one unmarked, and the other marked "Colored Men" and "Hombres Aqui"("Men Here"). No substantial evidence was offered to rebut the logical inference to be drawn from these facts. . . ${ }^{192}$

The Stone book contains absolutely no discussion of Mendez, Lopez, or Hernandez. Indeed, the authors went to some pains to excise Latinos/as from their materials. In their discussion of school desegregation cases, they present Keyes v. School District No. 1, Denver, Colo. ${ }^{193}$ as another case about desegregation involving Black students. ${ }^{194}$ The plaintiffs in the case, however, were Black and Latino, both groups having formed a coalition against de facto segregation. ${ }^{195}$ For the sake of telling a linear, Black/White story of struggles against segregation, the Stone casebook omits entirely the simultaneous and complementary history of segregation against Mexican Americans and their struggles for equality.

In the context of constitutional law, the paradigmatic presentation of the evolution of equality jurisprudence virtually guarantees that students will learn nothing about the history of racism and "separate but equal" segregation against Mexican Americans nor about the federal cases in which the courts found such segregation unconstitutional. How many of my present readers are aware that Mexican Americans, like Blacks, were lynched frequently? ${ }^{196}$ Mexican Americans were also segregated in separate but unequal schools, ${ }^{197}$ were kept out of public parks by law, ${ }^{198}$ were refused service in restaurants, ${ }^{199}$ were prohibited from attending "White" churches on Sundays, and were denied burial in "White" cemeteries, among all of the other horrors of the separate but equal scheme. ${ }^{200}$

192. Hernandez, 347 U.S. at $479-80$ \& n.10 (footnote omitted) (the bracketed material is quoted from footnote 10 of the opinion).

193. 413 U.S. 189 (1973).

194. See STONE ET AL., supra note 123 , at 518-22.

195. See Keyes, 413 U.S. at 195-96 \& n.6 (describing the tri-ethnic community in Denver, composed of Anglos, Negros, and Hispanics). Professor Martinez even describes the case as a "Mexican-American desegregation case." Martinez, supra note 39, at 595.

196. See, e.g., ACUÑA, supra note 70, at 34, 119-21.

197. See Westminister Sch. Dist. v. Mendez, 161 F.2d 774 (9th Cir. 1947).

198. See Lopez v. Seccombe, 71 F. Supp. 769 (S.D. Cal. 1944).

199. See ACuÑA, supra note 70, at 254 ("Throughout [World War II] Mexicans were treated as second-class citizens. For example, Sergeant Macario Garcia, from Sugarland, Texas, a recipient of the Congressional Medal of Honor, could not buy a cup of coffee in a restaurant in Richmond, Califormia. 'An Anglo-American chased him out with a baseball bat.' The Garcia incident was not isolated." (citation omitted)).

200. See McWilliams, supra note 141 , at 272-74. 
The paradigmatic, truncated presentation of racial and legal history that results from the Black/White binary paradigm ensures that most readers will never learn anything about Mexican American struggles for equality. A presentation of this omitted history, on the other hand, would present law students with a more complex and accurate sense of the scope of racism and the multiple struggles mounted against it. Cases such as Lopez, Mendez and Hernandez should be included in every book that discusses racism and segregation, especially books on constitutional law. Omit these cases, omit this history, and the vast majority of law students (and many law teachers) will have no clue that the Mexican-American struggle against segregation has been long and hard-fought in the courts. Omit these cases and most law students will have no clue that the Mexican American struggle against segregation has a place in our constitutional history. Omit these cases and we get the story of the struggle for equality told only in Black and White. We get only the paradigm, not the picture.

I have shown that the tendency to present a linear story of the development of equality doctrines corresponding to the Black/White paradigm leads to the omission of Mexican-American history. Robert Blauner describes more generally the omission of Chicano history by White scholars, which leads directly to reproduction of the Black/White paradigm and public ignorance about Latinos/as:

Even informed Anglos [and Blacks] know almost nothing about La Raza, its historical experience, its present situation, its collective moods. And the average citizen doesn't have the foggiest notion that Chicanos have been lynched in the Southwest and continue to be abused by the police, that an entire population has been exploited economically, dominated politically, and raped culturally. In spite of the racism that attempts to wipe out or, failing that, distort and trivialize the history and culture of the colonized, both expert and man in the street are far more aware of the past and present oppression suffered by blacks. ${ }^{201}$

Blauner refers to this continuing omission as "academic colonialism" by White scholars who persist in ignoring the history and problems encountered by Mexican Americans. ${ }^{202}$

Similar "academic colonialism" exists among constitutional law casebook authors who persist in omitting significant developments in constitutional law and history affecting Latinos/as, for the sake of a

201. BLAUNER, supra note 118 , at 166 .

202. See id. at 173. 
linear story within the Black/White binary paradigm. I want to know how casebook authors of constitutional law can justify leaving out the legal history I have described above. Do they deem it unimportant? If the reason for omitting Mexican-American legal history is a judgment that it is unimportant, how was that conclusion reached?

Adding this history presents a radically different picture of Latinos/as and Blacks struggling for equality and desegregation, and demonstrates some coalition between Latinos/as and Blacks in the struggle. ${ }^{203}$ Omitting this history offers us only a paradigmatic and distorted history in Black and White. The burden should be on constitutional law casebook authors to justify their decisions to omit this material, because its omission leads directly to a distorted picture of Latinos/as as nonparticipants and "spectators" in the struggle for civil rights.

\section{V \\ OBJECTIONS TO MY ANALYSIS}

I anticipate that there will be many objections to the analysis and arguments I have made in this Article. I believe I can anticipate at least some of the objections and offer some responses in the pages that follow.

One might object that I am distorting history by suggesting that slavery and the experience of Black Americans has not been of central importance in the formation of American society. I believe this objection misunderstands my argument. There can be no question, I think, that slavery and the mistreatment of Blacks in the United States were crucial building blocks of American society. ${ }^{204}$ The fact that the text of the Constitution protects slavery in so many places demonstrates the importance of slavery in the foundation of the country. ${ }^{205}$ The constitutional, statutory and judicial attempts to create more equality for Blacks, imperfect as these all have been, correspond to the history of mistreatment of Blacks.

203. See, e.g., GARCíA, supra note 140, at 58 ("Pete Tijerina reminded his colleagues in 1957 that Mexican Americans together with blacks would have little choice but to rely on federal intervention to ensure compliance of constitutional rights.").

204. See, e.g., Bell, supra note 172, at 60-61 ("American society as we know it exists only because of its foundation in racially based slavery, and it thrives only because racial discrimination continues.") (quoting Jennifer Hochschild, The New American Dilemma 5 (1984)).

205. See U.S. CoNST. art. I, $\S 9, \mathrm{cl} .1$ (prohibiting Congress from outlawing the slave trade until 1808); U.S. CoNST. art. I, $\$ 2$, cl. 3, amended by U.S. CoNST. amend. XIV, $\$ 2$ (calculating slaves as three-fifths of a person for the purposes of legislative apportionment); U.S. CoNST. art. IV, $\S 2, \mathrm{cl} .3$, repealed by U.S. CONST. amend XIII (requiring states to "deliver[] up" slaves and prohibiting states from discharging them); see also STONE ET AL., supra note 123, at 472-73. 
My argument is not that this history should not be an important focus of racial studies. Rather, my argument is that the exclusive focus on the development of equality doctrines based solely on the experience of Blacks, and the exclusive focus of most scholarship on the BlackWhite relationship, constitutes a paradigm which obscures and prevents the understanding of other forms of inequality, those experienced by non-White, non-Black Americans. The Black/White binary paradigm, by defining only Blacks and Whites as relevant participants in civil rights discourse and struggle, tends to produce and promote the exclusion of other racialized peoples, including Latinos/as, Asian Americans and Native Americans, from this crucial discourse which affects us all.

This exclusion is both the power and the stricture of the Black/White binary paradigm. Its power derives from the fact that a limited subject of inquiry makes possible the study of the Black-White relationship in extraordinary detail and with great insight. Its stricture, however, is that it has limited severely our understanding of how White racism operates with particularity against other racialized peoples. Furthermore, the binary paradigm renders the particular histories of other racialized peoples irrelevant to an understanding of the only racism-White racism against Blacks-that the paradigm defines to be important. This perceived irrelevance is why the history of Latinos/as, Asian Americans, and Native Americans is so frequently missing from the texts that structure our thinking about race.

One could defend the Black/White paradigm on the grounds that it represents the efforts of scholars to study the most virulent form of racism in the United States, White racism against Blacks, and that study of the most virulent form will naturally encompass less virulent forms such as those experienced by Latinos/as. The extent of White racism against Blacks, cruelly manifested in slavery, was unprecedented. Pervasive and continuing racism against Blacks justifies every effort dedicated to its eradication.

There are at least three reasons, however, why an exclusive focus on Blacks and Whites is not justified. First, it is important to work to eradicate all racism, not just the racism experienced by Blacks. Second, it is wrong to assume that racism against Latinos/as is simply a less virulent form of the same racism experienced by Blacks. As Blauner described, racism against Latinos/as has a different genesis. It may also be different in kind in ways that are very important. For example, Blacks may or may not ever experience the language and accent discrimination faced by many Latinos/as. Finally, our national demographics are changing significantly. One cannot simply ignore the concerns of an increasingly 
large and subordinated group of Latinos/as forever. A society is just only if everyone can participate in it on equal terms.

Some readers might object that Latinos/as are now, late in the game, attempting to lay claim to civil rights already hard won by Blacks after long struggle. I think the abbreviated slice of Mexican-American legal history presented in this article begins to refute this argument. In fact, Mexican Americans can lay claim to a long struggle for civil rights. Ironically, it is largely because of the Black/White paradigm of race that more people do not learn Mexican-American and other Latino/a history in the United States. So readers and scholars must begin to ask whether Latinos/as are invisible because they have not participated in social struggle or because scholars have been indifferent and have neglected to tell the stories of their presence and participation in social struggle. I suggest that the latter is the more accurate explanation.

It is not my intent to fault Black and White writers for writing solely about Blackness and its relation to Whiteness. Indeed, such writing has improved everyone's understanding of White racism against Blacks. On this subject, we need more, not less understanding. An important justification for focusing on Whiteness is that White racism is the source of the problems they explore. ${ }^{206}$ Such writing and scholarship is an act of struggle in itself and it need not be made in conjunction with or on behalf of any other group.

My objection to the state of most current scholarship on race is simply that most of this scholarship claims universality of treatment while actually describing only part of its subject, the relationship between Blacks and Whites. Race in the United States means more than just Black and White. It also refers to Latino/a, Asian, Native American, and other racialized groups. Accordingly, books titled "Race in America" or "White Racism" that only discuss Blackness and Whiteness claim a universality of scope that they do not deliver. These books offer a paradigmatic rendering of their subject that excludes important portions of civil rights history. Authors of such books need to be aware that they promulgate a binary paradigm of race that operates to silence and render invisible Latinos/as, Asian Americans and Native Americans. Accordingly, they reproduce a serious harm.

One could object to my conclusions on the grounds that White racism against Blacks has operated for a much longer time than racism against Latinos/as or Asians, and therefore the former problem needs to be studied and remedied first. English enslavement of Blacks can be

206. See, e.g., FEAGIN \& VerA, supra note 28 , at xi. 
traced to the early 1600 s, well before the nationhood of the United States. ${ }^{207}$ Encounters between Anglo and Mexican people did not begin on a large scale until the 1830 s, as Whites moved west into Texas and other parts of the Southwest that, at the time, were parts of Mexico. ${ }^{208}$ To a large extent, the Black/White binary paradigm of race has developed precisely because of the historical priority in time of White racism against Blacks and because of the nature of the exploitation that slavery caused. The question is whether the earlier deployment of White racism against Blacks in the United States justifies the binary approach in race scholarship and thimking today.

I cannot see scholarly efforts to understand and remedy White racism in all its forms as a "zero-sum game," in which efforts to understand other forms of White racism somehow take away from efforts to understand and remedy White racism against Blacks. My goal is not to take away anything from the study of White racism against Blacks. Rather, it is to identify some limitations of this study and to add to these studies the study of White racism against other racialized American groups. Stated simply, we must study and understand White racism in all its forms. Indeed, here lie some of the possibilities for coalition and for solving some of the problems that resist solution under our current scholarship. ${ }^{209}$

Another objection that critics might raise to this work is that I am merely substituting another, nearly equally oppressive paradigm for the Black/White binary paradigm. In other words, the critique would be that I am advocating a Black/White/Latino/a paradigm which would give Latinos/as more visibility but would render even more invisible Asian Americans, Native Americans, Gypsies, and other racialized groups. This is not the case. I have demonstrated that the Black/White binary paradigm renders invisible and irrelevant the history of every group other than Whites and Blacks. The rest of us become part of the undifferentiated mass of "minorities" or "people of color." While I have

207. See Lerone BenNetT, JR., Before the MAYflower 44-47 (5th rev. ed. 1984); EdMUND S. Morgan, American Slavery, American Freedom 297-300 (1975).

208. See generally AcuÑA, supra note 70, at 5-13; DAvid Montejano, ANglos and Mexicans IN THE Making of TeXas, 1836-1986 13-100 (1987). This does not mean that Mexican people were free from racism prior to their encounter with the English or with White Americans. Lighter-skinned Mexicans and, earlier, the few Spanish conquistadores discriminated severely against Mexieans in lower economic classes, who were typically darker-skinned and deemed more "Indian." See R. Douglas Cope, The Limits of Racial Domination 10-16 (1994).

209. See, e.g., Perea, supra note 114 , at $860-62,867-69$ (describing how a statutory focus on the physical and ethnic characteristics of both Blacks and Latinos/as that elicit discrimination could yield more just outcomes for members of both groups). 
used Mexican-American legal history to demonstrate the inadequacy of the Black/White paradigm, and I have written from my point of view as a Latino scholar, I have used this history to illustrate how much is lost in the service of normal science and research on race, and how the introduction of omitted history can present a radically different picture of what we are taught to believe about the story of struggles for equality. I know that just as much is lost regarding Asian-American and NativeAmerican legal history. In like manner, scholars must also present this omitted history prominently as part of the development of constitutional law and other legal subjects. ${ }^{210} \mathrm{My}$ argument is really an argument against the use of paradigms of race, against orthodox attempts to understand the experiences of every racialized group by analogy to Blacks, and for the development of particularized understanding of the histories of each and every racialized group.

Finally, I do not see my efforts as divisive. If anything, the paradigm I criticize is divisive because of its silencing of many groups. Coalition between Blacks and Latinos/as, for example, depends upon Latinos/as being active participants in debates about racism and racial justice. ${ }^{211}$ It requires mutual understanding of the particularities of each others' condition and of the particular ways in which White racism affects members of different groups.

210. Many writers, particularly writers in the field of critical race theory, have been writing such history, which needs to be made part of our textbooks. The sources I list are examples and therefore incomplete. For a comprehensive annotation of critical writings on Latinos/as and Latino/a History, see Jean Stefancic, An Annotated Bibliography, 85 CALIF. L. REv. 1509 (1997), 10 LA RAZA L.J. 423 (1997); see also, e.g., supra note 2 (listing pertinent sources); RoBERT A. WILLIAMS, JR., The American INDIAN IN Western Legal. Thought (1990), as well as his many fine articles; Pat K. Chew, Asian Americans: The "Reticent" Minority and Their Paradoxes, 36 WMI. \& MARY L. REV. 1 (1994); Michael A. Olivas, The Chronicles, My Grandfather's Stories, and Immigration Law: The Slave Traders Chronicle as Racial History, 34 ST. Lovis U. L.J. 425 (1990); Gerald Torres \& Kathryn Milun, Translating Yonnondio by Precedent and Evidence: The Mashpee Indian Case, 1990 Duke LJ. 625 (1990). On Gypsies, another forgotten group, see Walter Otto Weyrauch \& Maureen Anne Bell, Autonomous Lawmaking: The Case of the 'Gypsies,' 103 YaLe L.J. 323 (1993); Walter O. Weyrauch, Romaniya: An Introduction to Gypsy Law, and Oral Legal Traditions of Gypsies and Some American Equivalents, in Gypsy Law Symposium, 45 AM. J. CoMp. L. (forthcoming Spring 1997) (manuscripts on file with author).

211. See Elizabeth Martinez, Beyond Black/White: The Racisms of Our Time, 20 Soc. Just. 22, 22-23 (1992). Martinez describes the disadvantages of the Black/White binary paradigm, including how the paradigm discourages perception of common interests among people of color, most of whom are working class. Furthermore, if only Blacks perceive themselves as victims of racism, this perception isolates them from many potential allies, including Latinos/as and Asian Americans. 


\section{CONCLUSION}

The point of critical theory generally is to demonstrate shortcomings in our current understandings of legal and social structures and perhaps to suggest alternatives that improve upon these shortcomings. One implication of this Article is that, to the extent that critical theory has focused on questions of race, it is still tightly bound by the Black/White binary paradigm. Although this is much less true of critical race theory in particular, as some writers have focused on the points of view and histories of many racialized American groups, a true paradigm shift away froin the Black/White paradigm will only occur when such scholarship is more widely promulgated and accepted than is currently the case.

My review of important literature on race establishes the existence of the Black/White binary paradigm and its structuring of writing on race. The "normal science" of race scholarship specifies inquiry into the relationship between Blacks and Whites as the exclusive aspect of race relations that needs to be explored and elaborated. As a result, much relevant legal history and information concerning Latinos/as and other racialized groups is simply omitted from books on race and constitutional law.

The omission of this history is extraordinarily damaging to Mexican Americans and other Latinos/as. By omitting this history, students get no understanding that Mexican Americans have long struggled for equality. The absence of Latinos/as from histories of racism and the struggle against it enables people to maintain existing stereotypes of Mexican Americans. These stereotypes are perpetuated even by America's leading thinkers on race. Ignorance of MexicanAmerican history allows Andrew Hacker to proclaim that Hispanics are passive "spectators" in social struggle, ${ }^{212}$ and allows Cornel West to imply that Latino/a struggles against racism have been "slight though significant."213 To the extent that the legitimacy of claims for civil rights depends on a public perception of having engaged in struggle for them, the omission of this legal history also undermines the legitimacy of Latino/a claims for civil rights. This may explain why courts treat Latino/a claiıns of discrimination with such indifference.

Paradigmatic descriptions and study of White racism against Blacks, with only cursory mention of "other people of color," marginalizes all people of color by grouping them, without particularity, as somehow

212. See supra note 32 and accompanying text.

213. See supra note 57 and accompanying text. 
analogous to Blacks. "Other people of color" are deemed to exist only as unexplained analogies to Blacks. Thus, scholars encourage uncritical readers to continue to assume the paradigmatic importance of the Black/White relationship and to ignore the experiences of other Americans who also are subject to racism in profound ways.

Critical readers are left with many important questions: Beyond the most superficial understanding of aversion to non-White skin color, in what ways is White racism against Blacks explanatory of or analogous to White racism against Latinos/as, Asian Americans, Native Americans, and others? Given the unique historical legacy of slavery, what does a deep understanding of White-Black racism contribute to understanding racisms against other "Others?" Why are "other people of color" consistently relegated to parenthetical status and near-nonexistence in treatises purporting to cover their fields comprehensively?

It is time to ask hard questions of our leading writers on race. It is also time to demand better answers to these questions about inclusion, exclusion, and racial presence, than perfunctory references to "other people of color." In the midst of profound demographic changes, it is time to question whether the Black/White binary paradigm of race fits our highly variegated current and future population. Our "normal science" of writing on race, at odds with both history and demographic reality, needs reworking. 